\title{
Review \\ Elucidating the Response of Crop Plants towards Individual, Combined and Sequentially Occurring Abiotic Stresses
}

\author{
Khalid Anwar $^{1}$, Rohit Joshi ${ }^{1,2}{ }^{-1}$, Om Parkash Dhankher ${ }^{3}\left(\mathbb{D}\right.$, Sneh L. Singla-Pareek ${ }^{4}$ and Ashwani Pareek ${ }^{1,5, *(\mathbb{D})}$ \\ 1 Stress Physiology and Molecular Biology Laboratory, School of Life Sciences, Jawaharlal Nehru University, \\ New Delhi 110067, India; khalidbiochemistry@gmail.com (K.A.); joshirohit6@gmail.com (R.J.) \\ 2 Division of Biotechnology, CSIR-Institute of Himalayan Bioresource Technology, Palampur 176061, India \\ 3 Stockbridge School of Agriculture, University of Massachusetts Amherst, Amherst, MA 01003, USA; \\ parkash@umass.edu \\ 4 Plant Stress Biology, International Centre for Genetic Engineering and Biotechnology, \\ New Delhi 110067, India; sneh@icgeb.res.in \\ 5 National Agri-Food Biotechnology Institute (NABI), Mohali 140306, India \\ * Correspondence: ashwanip@mail.jnu.ac.in
}

check for

updates

Citation: Anwar, K.; Joshi, R.;

Dhankher, O.P.; Singla-Pareek, S.L.;

Pareek, A. Elucidating the Response

of Crop Plants towards Individual,

Combined and Sequentially

Occurring Abiotic Stresses. Int. J. Mol.

Sci. 2021, 22, 6119. https://

doi.org/10.3390/ijms22116119

Academic Editor: Juan Manuel Ruiz Lozano

Received: 19 April 2021

Accepted: 31 May 2021

Published: 6 June 2021

Publisher's Note: MDPI stays neutral with regard to jurisdictional claims in published maps and institutional affiliations.

Copyright: (c) 2021 by the authors. Licensee MDPI, Basel, Switzerland. This article is an open access article distributed under the terms and conditions of the Creative Commons Attribution (CC BY) license (https:/ / creativecommons.org/licenses/by/ $4.0 /)$.

\begin{abstract}
In nature, plants are exposed to an ever-changing environment with increasing frequencies of multiple abiotic stresses. These abiotic stresses act either in combination or sequentially, thereby driving vegetation dynamics and limiting plant growth and productivity worldwide. Plants' responses against these combined and sequential stresses clearly differ from that triggered by an individual stress. Until now, experimental studies were mainly focused on plant responses to individual stress, but have overlooked the complex stress response generated in plants against combined or sequential abiotic stresses, as well as their interaction with each other. However, recent studies have demonstrated that the combined and sequential abiotic stresses overlap with respect to the central nodes of their interacting signaling pathways, and their impact cannot be modelled by swimming in an individual extreme event. Taken together, deciphering the regulatory networks operative between various abiotic stresses in agronomically important crops will contribute towards designing strategies for the development of plants with tolerance to multiple stress combinations. This review provides a brief overview of the recent developments in the interactive effects of combined and sequentially occurring stresses on crop plants. We believe that this study may improve our understanding of the molecular and physiological mechanisms in untangling the combined stress tolerance in plants, and may also provide a promising venue for agronomists, physiologists, as well as molecular biologists.
\end{abstract}

Keywords: abiotic stress; climate change; combined stress; drought; flooding; heat; salinity; sequential stress

\section{Introduction}

In the coming decades, a significant rise in agricultural productivity will be required to meet the food requirements of $\sim 800$ million undernourished people, the number which has been further growing at an alarming pace, along with the shrinking arable land [1-3]. In addition, under changing climatic scenarios, this challenge is further exacerbated with predicted aggravation in the frequency and magnitude of extreme and unpredictable weather events, i.e., high temperature, drought, salinity and flooding that adversely affect crop productivity and global ecosystem diversity [3-6]. Hence, to ensure global nutritional and food security, development of climate-resilient crops is the need of the hour. Most abiotic stresses, occurring either in combination or sequentially, adversely influence the earth crust by modifying the physico-biochemical properties of water, soil, atmosphere, and consequently, plants face hostile conditions [4]. Thus, crop plants continuously face various combinations or sequences of diverse abiotic stresses under field conditions [7]. Such combined or sequential stresses elicit unique acclimation responses that cannot be 
observed by the application of any of the stress in isolation [7]. Combined or sequential occurrences of abiotic stresses can damage the crops more significantly than their individual occurrences during various developmental stages $[8,9]$. In response to these abiotic stresses, plants develop innumerable physiological, biochemical, cellular and molecular mechanisms to sense and respond against different abiotic stresses $[9,10]$. Until now, most of the the plant-environment interaction studies have been focused on crop responses against individual stress, which usually could not be replicated in a similar manner under actual field conditions where a complex interplay of multiple stresses occur, either in combination or sequentially [11].

Field conditions are often difficult to mimic experimentally as the outcome of combined or sequential stress significantly depends upon numerous factors, including the developmental stage, stress duration, severity, and sequence of individual stresses [12,13]. Recent evidence has shownthat combined or sequential stress may affect plant metabolism differently from individual stresses, and hence, shows several unique and common responses [14]. Table 1 presents representative examples where processes associated with changes in transcriptome, proteome, metabolome and morpho-physiology of the plants in response to combined high temperature and drought $(\mathrm{HT}+\mathrm{D})$ has been studied.Moreover, various stress regulatory genes and their signaling pathways have already been classified, depending upon the interaction between individual stresses [9]. However, little information is available onthe interaction between multiple stresses in plants [15].

Table 1. Representative examples showing the physiological and molecular processes studied in plants in response to combined high temperature and drought stress $(\mathrm{HT}+\mathrm{D})$.

\begin{tabular}{cllc}
\hline S.No. & Processes Studied & Crops & References \\
\hline 1 & Gene expression & Tobacco & {$[16]$} \\
\hline 2 & Transcriptome analysis & Arabidopsis & {$[17]$} \\
\hline 3 & Morpho-physiological traits & Agricultural crops & {$[8]$} \\
\hline 4 & Morpho-physiological traits & Agricultural crops & {$[11]$} \\
\hline 5 & Reactive Oxygen Species (ROS) & Agricultural crops & {$[18]$} \\
\hline 6 & Physiological and Proteome changes & Maize & {$[19]$} \\
\hline 7 & Proteome changes & Agricultural crops & {$[20]$} \\
\hline 8 & Proteome changes & Rice & {$[21]$} \\
\hline 9 & $\begin{array}{l}\text { Anti-oxidative enzymes, ABA } \\
\text { response and Proteome changes }\end{array}$ & Maize & {$[22]$} \\
\hline 10 & $\begin{array}{l}\text { Physiological and gene } \\
\text { expression response }\end{array}$ & Camellia oleifera & {$[23]$} \\
\hline 11 & Metabolic response & Maize & {$[24]$} \\
\hline 12 & Metabolic response & Rice & {$[25]$} \\
\hline 13 & Grain yield & Sorghum & {$[26]$} \\
\hline 14 & Grain growth and starch accumulation & Barley & {$[27]$} \\
\hline 15 & Genetic studies & Maize & {$[28]$} \\
\hline 16 & Antioxidant metabolism and lipid & Turfgrasses & {$[29]$} \\
\hline 17 & Peroxidation & Kentucky bluegrass & {$[30]$} \\
\hline
\end{tabular}

Plants are sessile organisms and have developed a remarkable capability to inhabit ecological niches that are regulated by their edaphic, as well as infrequent, heterogenous and chronic climatic extremes that have cyclic patterns [31]. Therefore, understanding the mechanisms underlying combined or sequential stress responses is crucial for discovering novel strategies and tools for the development of plant-resilient to suboptimal field condi- 
tions to ensure global food security and livelihood of billions of people [9,32]. Tremendous variations exist both within, and across, plant species in their ability to cope with these stresses. Technological advancements and modern genomic strategies developed over the last few decades have substantially improved our understanding of plant stress adaptation and acclimation. This has enhanced our basic understanding ofthe environmental and genetic interactions that play key roles in plant adaptation and yield stability [31].

The time has come to combine the views of plant physiologists, breeders and molecular biologists on combined or sequential stress, in order to gain a holistic understanding of the process to improve contemporary research prospects for sustainable crop ecosystems and improve productivity under changing climatic conditions [31]. However, our current priority is to characterize the available germplasm for multiple stress tolerant traits for the development of superior germplasm through breeding [9]. Therefore, understanding the complex biological traits underpinning crop yield and stress tolerance is critical [13]. In the present review, we have critically evaluated the information on various individual, combined or sequential stress responses in plants.Wehave also attemptedto identify the common potential molecular components underlying these responses.

\section{Impact of Individual, Combined and Sequential Stresses on Plants}

Despite a considerable increase in the number of abiotic stress related studies conducted during the past decade, most experiments have been focused on the response of plants to individual stress treatment under controlled conditions [24]. In contrast, under field conditions, numerous stresses can occur in combination or simultaneously, and may specifically alter plant metabolism than by individual stress treatments [17]. Due to higher frequency of the concurrent occurrence of multiple stresses under field conditions, the plant response may vary from that tested under laboratory conditions [33]. Therefore, to understand a holistic survival mechanism of plants, it is essential to study the combined and sequential abiotic stresses under the natural environment, which is still far less investigated [34]. Our knowledge of the molecular basis of the additive responses towards combined and sequential abiotic stresses is considerably less [24].

Plants, being sessile organisms, have evolved various physiological and biochemical mechanisms to adapt to extreme environmental conditions during their life cycle [35-37]. The level of plasticity against different stresses is regulated by the plant 's genetic background, along with the duration and severity of stress [15]. Abiotic stress signaling in plants is complex in nature [38] and involves different interacting signal transduction pathways especially during multiple stress tolerance, termed as 'crosstalk' [39]. Due to this crosstalk, the outcome of combined or sequential stress can either be neutral, additive, antagonistic, synergistic or sometimes unpredictable in nature (Table 2, Figure 1) [9]. For example, plants increase their transpiration rate by stomatal opening during heat stress, while under combined heat and drought stress, they close their stomata to reduce water loss [40]. Therefore, it is necessary to identify the molecular mechanisms behind the perception and adaptation under combined or sequential stresses [41].

Most of the environmental stresses have similar effects and responses, such as reduction in photosynthesis and growth, hormonal changes, oxidative damage, and the accumulation of stress-related proteins [42]. Besides stomatal closure, root water uptake capacity also plays a significant role in avoiding stress-induced growth reduction during dehydration [43]. Usually, heat stress occurs simultaneously with drought stress under field conditions, which makes studying their combined response indispensable, primarily in drought-stricken and semi-arid regions [44]. Numerous studies have examined the effect of combined heat and drought stress on the development and productivity of maize, barley, sorghum, and different grasses. The co-occurrence of drought and heat stresses would be anticipated largely to alter the physiological and morphological status, and metabolism, especially photosynthesis [45]. 


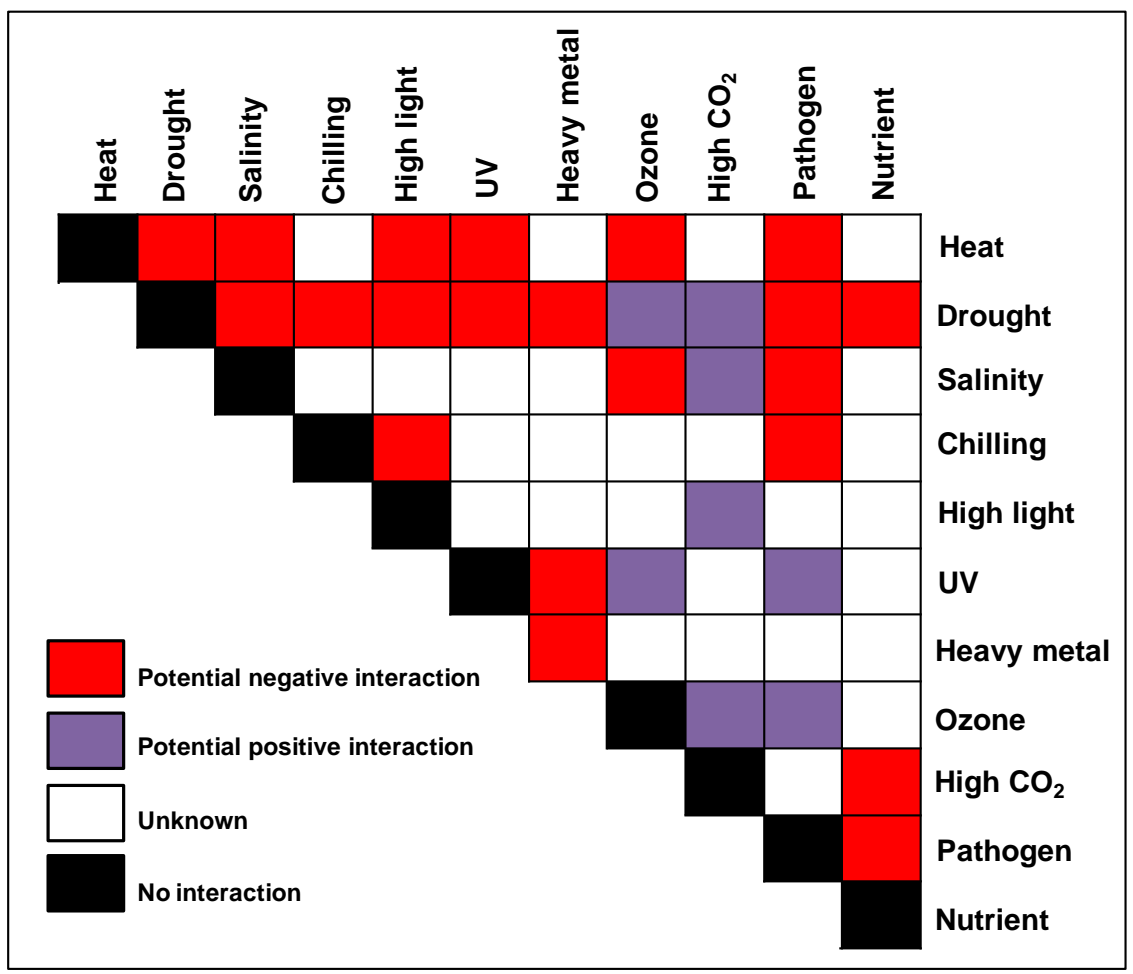

Figure 1. The stress matrix. Different combinations of potential environmental stresses that can affect crops in the field are shown in the form of a matrix. The color of the matrix indicates stress combinations that were studied with a range of crops and their overall effect on plant growth and yield. References for the combined studies are given in the Table 2.

Due to intensive irrigation, secondary salinization increases in semi-arid and arid agricultural regions, representing an excellent example of combined drought and salt stress [46,47]. Despite various stress-independent commonalities during osmotic stress, several stress-specific signatures have also been reported in different tissues at the level of transcriptome, metabolome and proteome during individual and combined salinity and drought stresses [11,15]. Under both drought and salinity stress, reduced photosynthesis, improved respiration rate, stomatal closure due to ABA signaling to reduce transpirational water loss and starch breakdown for energy production were observed [15,36].

In contrast to flooding, which restricts root growth, drought stress causes extensive or deeper root systems [48]. However, the duration and magnitude of both drought and flooding might be critical in determining species composition as drought may be lethal due to run-away xylem embolism [49]. Similarly, elevating sea levels and intrusion of seawater causes inland salinization, and along with heavy winds and high temperature, results in salt injury during different phases of the growing season [50,51]. Further, during postsubmergence, the limitations on water absorption cause drought-like symptoms, such as leaf wilting, rolling, and decreased relative water content [52]. Irrespective of the common symptoms of low temperature and salinity on plant growth and development [15], limited information is available about their combined effect on plants [53]. 
Table 2. Representative examples showing the specific interactions among various stress combinations on diverse plants.

\begin{tabular}{lllll}
\hline & Stress Combinations & Crop Plants & Outcomes during Combined Stress & References \\
\hline $\begin{array}{l}\text { Negative } \\
\text { response }\end{array}$ & Drought + salinity & Wheat & $\bullet$ & $\begin{array}{l}\text { Reduction in plant growth, biomass and net } \\
\text { photosynthetic rate is associated with root length and } \\
\text { root } \mathrm{K}^{+} / \mathrm{Na}^{+} \text {concentration. }\end{array}$
\end{tabular}

- $\quad$ Primary root length significantly reduced under

Maize combined stress.

- 53 metabolites were differentially regulated in primary roots under stress conditions.

- $\quad$ Stomatal closure, reduced photosynthesis, enhanced respiration, and leaf temperature.

Drought + high temperature
Tobacco

- $\quad$ Some transcripts induced during individual stress while suppressed during combined stress. Few transcripts were specifically induced during combined stress.

- $\quad$ Overlap between different transcription factors during individual and combined stress.

- 454 transcripts were specifically expressed during combined stress.

Arabidopsis - Sucrose, maltose and glucose were highly accumulated under combined stress.

- Proline only accumulated during drought stress.

- $\quad$ Photosynthesis rate declined under High temperature > Drought $>$ combined stress.

Wheat

- High temperature significantly affects grain number, while drought affects grain weight and combined stress affects leaf chlorophyll content, spikelet fertility, total dry weight, and harvest index.

- Root allocation increased during drought, while reproductive allocation, hyponasty and specific leaf area

Arabidopsis increased under high temperature.

- Origin of accession plays a significant role during individual and combined stress.

- Combined stress in comparison to a single stress strongly affected the seminal lateral roots, reducing the dry weight, length, surface area and root mass ratio (RMR).

- Effect of abiotic stress is cultivar-dependent where the sensitive genotypes were more affected by combined

Drought + chilling Sugarcane stress than tolerant genotypes.

- Low root temperature combined with drought severely affects PSII activity.

- Interaction among ABA, JA, and ethylene signaling pathways regulate pathogen-, wound-, and dehydration-response and one signaling pathway may dominate over others, depending on the stress conditions.

- 11 genes differentially regulated, 23 genes specifically

Arabidopsis regulated, and reduced expression of $\mathrm{R}$-gene mediated response were observed under combined heat, drought, and turnip mosaic virus stress.

- Combined stress induces responses that can be

Drought + UV Plants antagonistic, additive or synergistic in comparison to individual stresses which results from interplay between metabolic shuts. 
Table 2. Cont.

\begin{tabular}{|c|c|c|c|}
\hline Stress Combinations & Crop Plants & Outcomes during Combined Stress & References \\
\hline Drought + high light & Arabidopsis & $\begin{array}{l}\text { Mutant seedlings deficient in alternative oxidase (AOX) } \\
\text { showed accumulation of anthocyanins in leaves, } \\
\text { alterations in photosynthetic efficiency, increased } \\
\text { superoxide radical and reduced root growthunder } \\
\text { combined stress. }\end{array}$ & {$[62]$} \\
\hline Drought + low N & Wheat & $\begin{array}{l}\text { - Low N stress can lead to accumulation of ABA in wheat } \\
\text { seedlings. } \\
\text { - Combined stress was found to have significant } \\
\text { interaction in regulation of genes for nitrate signaling, } \\
\text { uptake and assimilation. }\end{array}$ & [63] \\
\hline $\begin{array}{l}\text { Drought + heavy } \\
\text { metals }\end{array}$ & Red maple & $\begin{array}{l}\text { - Combined stress has additive effect in both stems and } \\
\text { roots, reductions in hydraulic conductance, } \\
\text { xylem-specific conductivity, and leaf-specific } \\
\text { conductivity. }\end{array}$ & [64] \\
\hline $\begin{array}{l}\text { Drought }+ \text { soil } \\
\text { compaction }+ \\
\text { mechanical stress }\end{array}$ & Tobacco & $\begin{array}{l}\text { Plant growth and fine root proportion was reduced, } \\
\text { while root diameter and xylem area increased under } \\
\text { combined stress. }\end{array}$ & [65] \\
\hline Drought + nutrient & Mungbean & $\begin{array}{l}\text { - Under combined stress, a significant reduction in gas } \\
\text { exchange traits (photosynthesis, stomatal conductance, } \\
\text { transpiration, instantaneous water use efficiency), and P } \\
\text { uptake in seed and shoot were observed under combined } \\
\text { stress as compared to individual stress. }\end{array}$ & [66] \\
\hline $\begin{array}{l}\text { Salinity +high/low } \\
\text { temperature } \\
\text { Drought }+ \text { high/low } \\
\text { temperature }\end{array}$ & Wheat & $\begin{array}{l}\text { - } \quad \text { Root and shoot elongation significantly reduced under } \\
\text { individual stress. } \\
\text { - } \quad \text { HT/LT treatment possess additive effect on growth } \\
\text { inhibition under salt stress. } \\
\text { - } \alpha \text {-tocopherol significantly increased under drought and } \\
\text { salt stress but significantly decreased under HT stress. }\end{array}$ & [67] \\
\hline $\begin{array}{l}\text { Salinity + high } \\
\text { temperature }\end{array}$ & Suaeda salsa & $\begin{array}{l}\text { - } \quad \text { Combined stress suppressed } \mathrm{CO}_{2} \text { assimilation and } \\
\text { photosystem II efficiency. } \\
57 \text { differentially expressed proteins were observed under } \\
\text { individual and combined stress. } \\
\text { Expression of nucleoside diphosphate kinase 1, } \\
\text { chlorophyll a/b binding protein, and ABC transporter I } \\
\text { family member } 1 \text { was specifically induced during } \\
\text { combined stress. }\end{array}$ & {$[68]$} \\
\hline Salinity + pathogen & Rice & $\begin{array}{l}\text { Downregulation of OsMAPK5 expression enhanced } \\
\text { pathogenesis-related (PR) genes expression and } \\
\text { significantly enhanced resistance to fungal (Magnaporthe } \\
\text { grisea) and bacterial (Burkholderia glumae) pathogens but } \\
\text { reduced tolerance to drought, salt, and cold. In contrast, } \\
\text { overexpression lines exhibited increased OsMAPK5 } \\
\text { kinase activity and increased tolerance to drought, salt, } \\
\text { and cold stresses. }\end{array}$ & [69] \\
\hline $\begin{array}{l}\text { High temperature + } \\
\text { ozone }\end{array}$ & $\begin{array}{l}\text { Silver birch } \\
\text { (Betula } \\
\text { pendula) }\end{array}$ & $\begin{array}{l}\text { - } \mathrm{O}_{3} \text { reduces, while temperature increase tree growth and } \\
\text { growth may be counteractive during combined stress. } \\
\mathrm{R}: \mathrm{S} \text { ratio decreases under } \mathrm{O}_{3} \text { exposure. } \\
\text { Temperature increase may stimulate soil respiration rates } \\
\text { and total biomass, while } \mathrm{O}_{3} \text { could have opposite effect. } \\
\text { Elevated } \mathrm{O}_{3} \text { decreases } \mathrm{C} \text { assimilation, foliar } \mathrm{C} \text { content } \\
\text { and productivity. }\end{array}$ & {$[70]$} \\
\hline
\end{tabular}


Table 2. Cont.

\begin{tabular}{|c|c|c|c|}
\hline Stress Combinations & Crop Plants & Outcomes during Combined Stress & References \\
\hline $\begin{array}{l}\text { High temperature + } \\
\text { pathogen }\end{array}$ & Arabidopsis & $\begin{array}{l}\text { - NB-LRR type of R or R-like protein is the temperature } \\
\text {-sensitive component of plant defense responses. } \\
\text { Alterations in the R-like gene } S N C 1 \text { and the } R \text { gene } N \text { can } \\
\text { change temperature sensitivity of defense responses. }\end{array}$ & [71] \\
\hline $\begin{array}{l}\text { High temperature + } \\
\text { UV-C }\end{array}$ & Strawberry & $\begin{array}{l}\text { Both heat and combined treatments, decreased hue and } \\
\text { delayed changes in the colorimetric parameters. } \\
\text { The combined stress treatment reduced fungal infections } \\
\text { and delayed in vitro germination of Botrytis cinerea } \\
\text { conidia. } \\
\text { Neither the heat nor UV-C irradiation modified the total } \\
\text { sugar content, although the combined treatment } \\
\text { decreased it slightly relative to the control. } \\
\text { The combination of UV-C and heat treatments enhanced } \\
\text { the benefits of applying each treatment separately and } \\
\text { could be useful to improve and extend strawberry fruit } \\
\text { postharvest life. }\end{array}$ & [72] \\
\hline $\begin{array}{l}\text { High temperature + } \\
\text { high light }\end{array}$ & $\begin{array}{l}\text { Sunflower } \\
\text { (Helianthus } \\
\text { annuus) }\end{array}$ & $\begin{array}{l}\text { - Comparative expression analysis of leaves and immature } \\
\text { seeds revealed that } 89,113 \text { and } 186 \text { genes were } \\
\text { differentially expressed in response to HL, HT and HL + } \\
\text { HT, respectively. }\end{array}$ & [73] \\
\hline $\begin{array}{l}\text { High temperature + } \\
\mathrm{CO}_{2}\end{array}$ & $\begin{array}{l}\text { Soybean } \\
\text { and maize }\end{array}$ & $\begin{array}{l}\text { - Increased photosynthetic rates in response to } \mathrm{CO}_{2} \\
\text { enrichment, while } \mathrm{C}_{4} \text { cycle is largely unresponsive to } \\
\text { increased response to } \mathrm{CO}_{2} \text { enrichment. } \\
\mathrm{CO}_{2} \text { enrichment can mitigate the effects of moderately } \\
\text { elevated temperatures on crop yield. }\end{array}$ & {$[74]$} \\
\hline $\begin{array}{l}\text { Low temperature + } \\
\text { pathogen }\end{array}$ & Plants & $\begin{array}{l}\text { Both virus and transgene-triggered RNA silencing are } \\
\text { inhibited at low temperature. Thus, plants become more } \\
\text { susceptible to viruses. RNA silencing-based phenotypes } \\
\text { of transgenic plants are lost. However, temperature does } \\
\text { not influence the accumulation of micro (mi) RNAs, } \\
\text { which play a role in developmental regulation. }\end{array}$ & [75] \\
\hline $\begin{array}{l}\text { Low temperature + } \\
\text { high light }\end{array}$ & $\begin{array}{l}\text { Dunaliella } \\
\text { salina }\end{array}$ & $\begin{array}{l}\text { - Low temperature and combined high light-low } \\
\text { temperature decreased chlorophyll and } \beta \text {-carotene } \\
\text { indicating that these treatments cause photo-oxidative } \\
\text { stress. } \\
\text { High light, low temperature and combined high } \\
\text { light-low temperature treatments increased the total } \\
\text { ascorbate pool by } 10-50 \% \text { and the total glutathione pool } \\
\text { by } 20-100 \% \text { with no consistent effect on their redox state. }\end{array}$ & [76] \\
\hline Pathogen + nutrient & Arabidopsis & $\begin{array}{l}\text { Field study on potassium disease interaction which } \\
\text { provides evidence that facilitated entry and development } \\
\text { of pathogens or insects in(to) potassium-deficient plants } \\
\text { as a result of physical and metabolic changes is } \\
\text { counteracted by an increased defense. }\end{array}$ & [77] \\
\hline UV-B + Heavy metals & Pea & $\begin{array}{l}\text { - Combined dose (UV-B + 0.01 mM Ni) caused inhibitory } \\
\text { effects. } \\
\text { Nickel at high doses strongly inhibited PSII activity and } \\
\text { the inhibition was further intensified when chloroplasts } \\
\text { were simultaneously exposed to UV-B radiation. } \\
\text { High doses of Ni }(0.1 \text { and } 1.0 \mathrm{mM} \text { ) and UV-B alone } \\
\text { interrupted electron flow at the oxygen evolving } \\
\text { complex. Similar damaging effects were caused by } 0.01 \\
\text { and } 0.1 \mathrm{mM} \text { Ni together with UV-B, but the damage } \\
\text { extended to PSII reaction center, in case of } 1.0 \mathrm{mM} \mathrm{Ni} \text { in } \\
\text { combination with UV-B. }\end{array}$ & [78] \\
\hline
\end{tabular}


Table 2. Cont.

\begin{tabular}{|c|c|c|c|c|}
\hline & Stress Combinations & Crop Plants & Outcomes during Combined Stress & References \\
\hline & Nutrient + high $\mathrm{CO}_{2}$ & $\begin{array}{l}\text { Panicum } \\
\text { maximum } \\
\text { Jacq. } \\
\text { 'Mombaça' } \\
\text { (Guinea } \\
\text { grass) }\end{array}$ & $\begin{array}{l}\text { - Under the combination of }\left[\mathrm{eCO}_{2}\right] \text { and elevated } \\
\text { temperature }[\mathrm{eT}] \text { conditions, productivity increases along } \\
\text { with the nutritional requirement for N, Ca and S. }\end{array}$ & [79] \\
\hline & $\begin{array}{l}\text { Heavy metals + } \\
\text { heavy metals }\end{array}$ & Tomato & $\begin{array}{l}\text { - Zn supply clearly reduced Cd accumulation in leaves } \\
\text { and simultaneously increased Zn concentration. } \\
\text { Cd-induced oxidative stress in leaves as indicated by an } \\
\text { increase in thiobarbituric acid-reactive substances } \\
\text { (TBARS) level and chlorophyll breakdown. } \\
\text { - Zn supplementation, at low level, restored and enhanced } \\
\text { the functional activity of these enzymes (SOD, CAT, APX } \\
\text { and GR) as compared to Cd-alone-treated plants. } \\
\text { The beneficial effect of adequate Zn level on Cd toxicity } \\
\text { was confirmed by a significant decrease in TBARS level } \\
\text { and restoration of chlorophyll content. However, when } \\
\text { Zn was added at a high level in combination with Cd, } \\
\text { there was an accumulation of oxidative stress, which was } \\
\text { higher than that for Cd or excess Zn alone treatments. }\end{array}$ & [80] \\
\hline \multirow[t]{2}{*}{$\begin{array}{l}\text { Positive } \\
\text { response }\end{array}$} & \multirow[t]{2}{*}{ Drought + ozone } & Birch & $\begin{array}{l}\text { - Combined stress increases the N concentration in the } \\
\text { leaves, the thickness of the upper epidermal cell wall, the } \\
\text { number of pectinaceous projections of mesophyll cell } \\
\text { walls, and the vacuolar tannin-like depositions and } \\
\text { phenolic droplets, which are regarded as signs of } \\
\text { activated stress defense mechanisms. } \\
\text { The increase in specific foliage mass, cytoplasmic lipids } \\
\text { (younger leaves), and a condensed appearance of the } \\
\text { upper epidermal mucilaginous layer were caused by both } \\
\text { drought and ozone but were not additive. }\end{array}$ & [81] \\
\hline & & $\begin{array}{l}\text { beech trees } \\
\text { (Fagus } \\
\text { sylvatica) }\end{array}$ & $\begin{array}{l}\text { - Photosynthesis (Amax), stomatal conductance }(g \mathrm{~s}) \text {, and } \\
\text { electron transport rate (ETR) were lowered during } \\
\text { drought rather than ozone, whereas chlorophyll levels } \\
\text { did not differ. } \\
\text { Comparison of AOT40 [Accumulated Ozone exposure } \\
\text { over a threshold of } 40 \mathrm{ppb}\left(\left(80 \mu \mathrm{g} / \mathrm{m}^{3}\right)\right] \text {, an } \mathrm{O}_{3} \\
\text { exposure-based risk index of } \mathrm{O}_{3} \text { stress, and cumulative } \\
\text { ozone uptake (COU) yielded a linear relationship } \\
\text { throughout humid growth conditions. The findings } \\
\text { support the hypothesis that drought protects plants from } \\
\mathrm{O}_{3} \text { injury by stomatal closure, which restricts } \mathrm{O}_{3} \text { influx } \\
\text { into leaves and decouples COU from high external ozone } \\
\text { levels. } \\
\text { High AOT40 erroneously suggested high } \mathrm{O}_{3} \text { risk under } \\
\text { drought. Enhanced ozone levels did not aggravate } \\
\text { drought effects in leaves and stem. }\end{array}$ & [82] \\
\hline
\end{tabular}


Table 2. Cont.

Stress Combinations Crop Plants

Outcomes during Combined Stress

References

- Medicago truncatula cultivar Jemalong that is sensitive to ozone and drought stress when applied singly, showed tolerance when subjected to a combined application of these stresses.

- Lowered stomatal conductance may be a vital tolerance mechanism to overcome combined ozone and drought.

- $\quad$ Sustained increases in both reduced ascorbate and glutathione in response to combined stress may play a role in lowering reactive oxygen species and nitric oxide toxicity.

- Transcriptome analysis indicated that genes associated with glucan metabolism, responses to temperature and

Medicago truncatula

Drought + high $\mathrm{CO}_{2} \quad$ Plants light signaling may play a role in dampening ozone responses due to drought-induced stomatal closure during combined occurrence of these two stresses.

- Gene ontologies for jasmonic acid signaling and innate immunity were enriched among the 300 differentially expressed genes unique to combined stress.

- Differential expression of transcription factors associated with redox, defense signaling, jasmonate responses and chromatin modifications may be important for evoking novel gene networks during combined occurrence of drought and ozone.

- The alterations in redox milieu and distinct transcriptome changes in response to combined stress could aid in tweaking the metabolome and proteome to annul the detrimental effects of ozone and drought in Jemalong.

- $\quad$ Elevated atmospheric $\mathrm{CO}_{2}$ cause an increase in leaf and canopy photosynthesis, especially in $\mathrm{C} 3$ plants, with minor changes in dark respiration. Additional $\mathrm{CO}_{2}$ causes an increase in biomass without marked alteration in dry matter partitioning, reduced transpiration of most plants and improvement in WUE. However, spatiotemporal variation in these attributes impact agronomic performance and crop water use in a site-specific manner. Nutrient acquisition is closely associated with overall biomass and strongly influenced by root surface area.

- The combination of heat and salinity provides a significant level of protection to tomato plants from the effects of salinity. We observed a specific response of plants to the stress combination, which included accumulation of glycine betaine and trehalose. The

salinity + High temperature tomato accumulation of these compounds under the stress combination was linked to the maintenance of a high $\mathrm{K}^{+}$concentration and thus a lower $\mathrm{Na}^{+} / \mathrm{K}^{+}$ratio, with a better performance of the cell water status and photosynthesis as compared with salinity alone.

- Combined stress favored root biomass production increasing number and elongation of roots.

- $\quad$ Elevated $\mathrm{CO}_{2}$ and its combination with salinity or high light increases biomass production.

Salinity + high $\mathrm{CO}_{2} \quad$ lettuce

- Elevated $\mathrm{CO}_{2}$ and its combination with salinity or high light increases the antioxidant capacity, while high light treatment alone increased the antioxidant capacity of red-leaf lettuce, but not of green-leaf lettuce. 
Table 2. Cont

\begin{tabular}{|c|c|c|c|}
\hline Stress Combinations & Crop Plants & Outcomes during Combined Stress & References \\
\hline Salinity + boron & Zea mays & $\begin{array}{l}\text { Under salt stress, the activity of specific membrane } \\
\text { components can be influenced directly by boron, } \\
\text { regulating the water uptake and water transport through } \\
\text { the functions of certain aquaporin isoforms. }\end{array}$ & [87] \\
\hline \multirow[t]{2}{*}{ Ozone + pathogen } & Plants & $\begin{array}{l}\text { Cellular responses to these environmental challenges are } \\
\text { rather similar, which might be the reason why plants that } \\
\text { are resistant to one stress are sometimes cross-tolerant to } \\
\text { others. }\end{array}$ & [88] \\
\hline & Microbes & $\begin{array}{l}\text { - The acetate, propionate, and butyrate buffered aqueous } \\
\text { ozone combinations had a significant } 3-4 \text { log reduction of } \\
\text { S. aureus }(p<0.05) \text { colony forming unit }(\mathrm{CFU}) \text {, while } \\
\text { citrate or oxalate buffered aqueous ozone, statistically } \\
\text { significant versus buffer alone, had less activity. }\end{array}$ & [89] \\
\hline Ozone + UV & $\begin{array}{l}\text { Escherichia } \\
\text { coli }\end{array}$ & $\begin{array}{l}\text { Ozone was found to be a stronger disinfectant than UV } \\
\text { radiation, using both simultaneously was more effective } \\
\text { than using them individually. }\end{array}$ & [90] \\
\hline Ozone + high $\mathrm{CO}_{2}$ & Rice & $\begin{array}{l}\text { Elevated } \mathrm{CO}_{2}(627 \mathrm{ppm}) \text { increases rice yields by } 23 \% \text {. } \\
\text { Modest increases in grain mass and larger increases in } \\
\text { panicle and grain number contributed to this response. } \\
\text { The response of rice to elevated } \mathrm{CO}_{2} \text { varied with } \\
\text { fumigation technique. The more closely the fumigation } \\
\text { conditions mimicked field conditions, the smaller was } \\
\text { the stimulation of yield by elevated } \mathrm{CO}_{2} \text {. } \\
\text { Free air concentration enrichment (FACE) experiments } \\
\text { showed only a } 12 \% \text { increase in rice yield. } \\
\text { When compared with rice grown in charcoal-filtered air, } \\
\text { rice exposed to } 62^{\circ} \text { ppb } \mathrm{O}_{3} \text { showed a } 14 \% \text { decrease in } \\
\text { yield. Many determinants of yield, including } \\
\text { photosynthesis, biomass, leaf area index, grain number } \\
\text { and grain mass, were reduced by elevated } \mathrm{O}_{3} \text {. }\end{array}$ & [91] \\
\hline Pathogen + UV & $\begin{array}{l}\text { Various } \\
\text { plants }\end{array}$ & $\begin{array}{l}\text { Cellular responses to these environmental challenges are } \\
\text { rather similar, which might be the reason why plants } \\
\text { resistant to one stress are sometimes cross-tolerant to } \\
\text { others. }\end{array}$ & [88] \\
\hline $\begin{array}{l}\text { High } \mathrm{CO}_{2}+\text { high } \\
\text { light }\end{array}$ & lettuce & $\begin{array}{l}\text { High light treatment alone increased production in } \\
\text { green-leaf lettuce but not in red-leaf lettuce. On the other } \\
\text { hand, elevated } \mathrm{CO}_{2} \text { and its combination with salinity or } \\
\text { high light increased the antioxidant capacity, while high } \\
\text { light treatment alone increased the antioxidant capacity } \\
\text { of red-leaf lettuce, but not of green-leaf lettuce. }\end{array}$ & [86] \\
\hline
\end{tabular}

\subsection{Physiological, Growth and Developmental Processes}

Plants induce various interacting signal transduction pathways when exposed to different stress combinations [39]. In general, combined or sequential stress evoke distinct responses in plants than individual stresses in physiological, molecular and metabolic networks, which influence nutrient assimilation and distribution [32], yet share common pathways and responses. Studies applying combined stress scenarios to mimic field conditions are increasing [11]. These studies strongly focus on comparative transcriptomics of abiotic and biotic interactions. The integration of various metabolic pathways and the crosstalk between different sensors and signal transduction pathways further augments combined stress response [92]. Current studies on the transcriptome analysis of combined stress response mainly represent a snapshot of a single time point. The sequential stress exposures induce priming [93], which allows plant to respond rapidly in future environ- 
mental vagaries [11]. Combined stress results in oxidative stresses, which modulate sugar levels, plant growth and stress responses [11]. This has allowed the characterization of genes specific to individual, combined or sequential stress conditions [11].

As recent research has indicated, temperatures higher than $35^{\circ} \mathrm{C}$ affect germination, vegetative, reproductive, grain filling stages and ultimately yields [94]. However, the reproductive stage is more sensitive to combined drought and heat stress, whilst each stress differentially affects reproductive traits [7]. Earlier reports demonstrated that combined drought and heat stress shows similar tolerance mechanism to individual stresses, including the accumulation of compatible solutes, protective proteins, activation of nonenzymatic and enzymatic antioxidant system [95,96]. Similarly, alterations in physiological processes, including photosynthesis, lipid accumulation, oxidative metabolism, and transcript abundance was observed [10], affecting membrane stability, stomatal conductance, reduced leaf area and water-use efficiency $[97,98]$.

Under field conditions, heat and drought stresses occur simultaneously resulting in strikingly varied responses that cannot be inferred from their individual responses [99], which is also species specific [40]. High temperature causes stomatal opening to increase transpiration and leaf surface cooling, long, slender leaves with a higher specific leaf area and decreased root development [60]. In contrast, drought reduces leaf stomatal conductance and leaf area, resulting in enhanced canopy temperature by $2-5^{\circ} \mathrm{C}$, while improved root development to prevent water loss and ABA accumulation [36,100]. Whereas, stomata remain closed during combined drought and heat stress, leading to reduced membrane stability, relative water content, plant length, shoot fresh/ dry weight, stem diameter, leaf area, kernels/ear, 100-kernel weight, harvest index, seed abortion and reduced yield in potato, wheat and maize [101-103]. In addition, enhanced respiration rate due to breakdown of reserved assimilate provides energy for acclimation under combined drought and heat stress to mitigate $\mathrm{CO}_{2}$ assimilation loss [104]. Therefore, under natural field conditions, co-occurrence of heat and drought stress requires different strategies for acclimation [92].

Global climate change involvesincreased flooding events, which is detrimental to plant growth and productivity in agricultural ecosystems [105]. Different parameters, such as leaf area, shoot dry weight, photosynthesis, transpiration, absorption and transport of nutrients, panicle number, panicle weight, harvest index drastically reduce under turbid floodwater [51,106]. To confer enhanced adaptation and survival during energy starvation, plants develop mechanisms to survive during transient influx of water, which include energy generation through fermentation under hypoxia, adventitious roots/aerenchyma development for aeration, petiole and internode elongation to outgrow submergence, reduction in epidermal cell wall and cuticle thickness for reduced diffusion resistance $[106,107]$. In addition, gas films on the leaf surface hamper the salt entry into leaves [106]. Further, after desubmergence plants were abruptly exposed to higher oxygen and light intensity causing oxidative damage to photosystem II reaction centers and desiccation of leaves due to reduced hydraulic conductivity in shoots and mineral leaching [108]. Coastal flooding causes combined salinity and submergence, causing oxygen deprivation and restricted energy production for ion transport resulting in accumulation of $\mathrm{Na}^{+}$and $\mathrm{Cl}^{-}$and reduces $\mathrm{K}^{+}$ concentration. Halophytes inhabiting coastal regions preserve more pigment, chloroplast structure [109], develop aerenchyma and maintain antioxidant systems and activate the hormonal and signaling pathways [106].

\subsection{Photosynthesis and Respiration}

Photosynthesis, i.e., photo-assimilate production and carbon assimilation are the most sensitive physiological processes to adverse environmental conditions [110]. Improved integrity of the photosynthetic apparatus often holds the key for stress tolerant genotypes. Photosystem II electron transport is the most sensitive segment of the photosynthetic machinery [15] and its structural and functional ability gets disrupted under adverse environments [15]. Drought stress regulates photosynthesis through stomatal closure and reduced $\mathrm{CO}_{2}$ uptake and diffusion into mesophyll tissues, favoring oxygenase 
activity (Figure 2) [111,112], decline in ribulose 1,5-bisphosphate carboxylase/oxygenase (Rubisco) and ribulose bisphosphate (RuBP) activity [112], impairment of ATP synthesis, and photo-phosphorylation resulting in decline in crop biomass and yield [113]. Similarly, at temperatures higher than $35^{\circ} \mathrm{C}$, photosynthesis becomes considerably reduced [114]. At higher temperatures, oxygen solubility and Rubisco activity is reduced, causing higher photorespiration and lower photosynthesis [115]. In addition, high temperature enhances thylakoid membrane fluidity, leading to dislodging of PSII light harvesting complexes from thylakoid membrane, indicated by steep rise in basal level of chlorophyll fluorescence [116]. Similarly, cold and salt stress individually render adverse effects on photosynthetic electron transport chain by impairing performance of photosynthetic rate and photochemical efficiency in crops such as sunflower, bean and maize [53,117-119]. However, limited information related to the effects of combined salt and cold on photosynthesis is available [53]. Similarly, salinity and drought also negatively affect photosynthesis by limiting internal $\mathrm{CO}_{2}$ through stomatal closure [11].
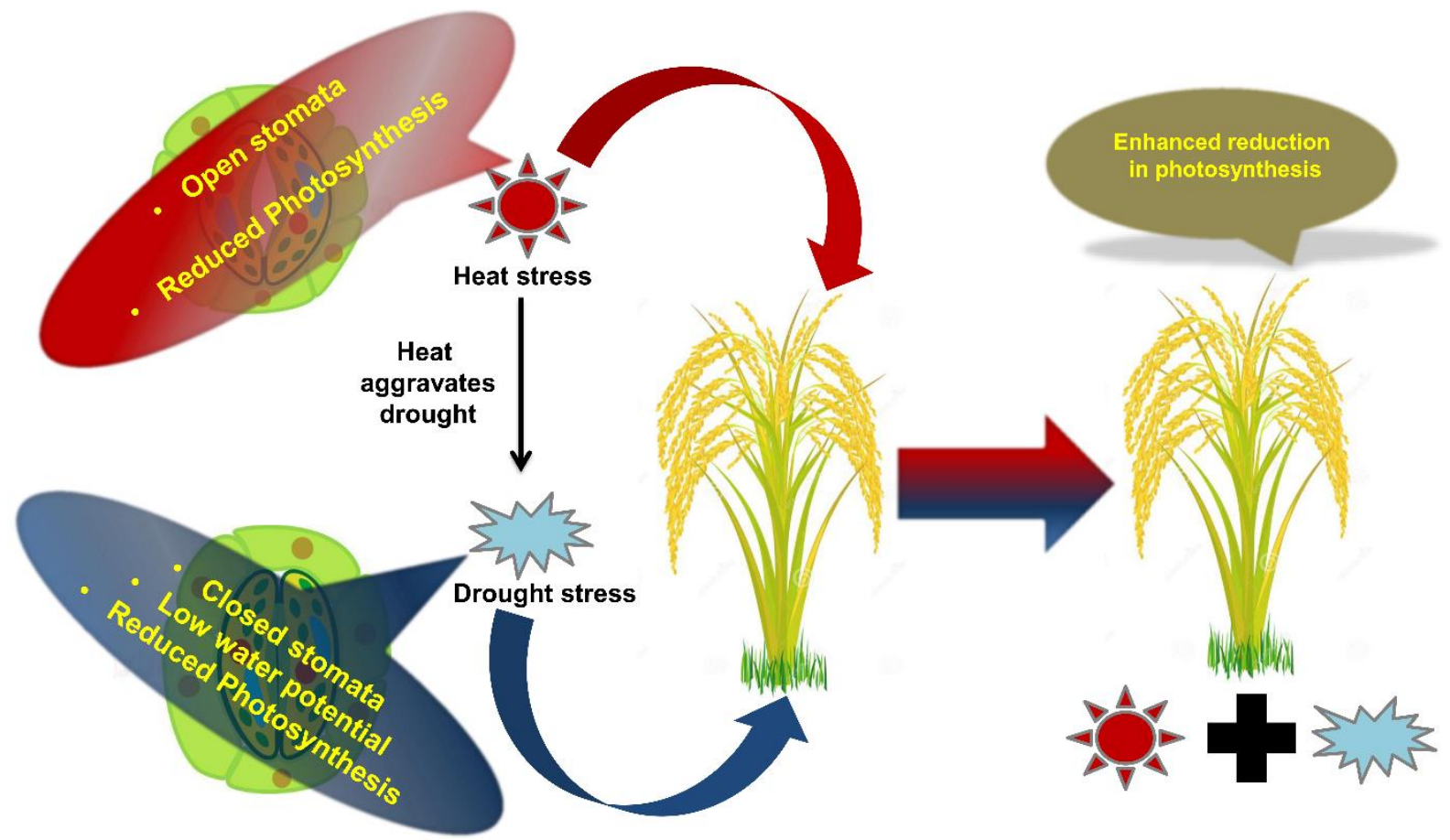

Figure 2. Schematic representation showing the effects of combined stress on plants. Effect of combined stresses on plants is explained taking an example of heat and drought. For example, simultaneous exposure to heat and drought leads to enhanced retardation of physiological processes such as photosynthesis.

Mitochondrial respiration plays a pivotal role in determining the growth and survival of plants and is reduced under drought and temperature stress [120]. However, under field conditions, high temperature stress is associated with soil temperature and drought. Increased respiratory losses by grains or kernels under heat stress can offset the increased influx of assimilation resulting in higher yield losses [121]. Both stresses (heat and drought) increases membrane fluidity, leakiness and reduces integrity of the proteins and membranes. This leads to a decline in photosynthesis before respiration losses and enhanced photorespiration. Therefore, both drought and heat stress combination may, thus, be additive or multiplicative and exacerbates each other effects [122,123]. Combined drought and heat stress influences diurnal, as well as seasonal patterns of leaf water potential, carbohydrate content, photo-assimilate translocation and stomatal conductance associated with senescence [94,124]. The response pattern of crops under heat and drought stress during various growth stages can be the basis for selecting multiple stress tolerant variety to solve yield stability and nutritional crisis [113]. Similarly, flooding stress reduces 
hydraulic conductance of roots [125], caused either by oxygen deprivation or accumulation of $\mathrm{CO}_{2}$ around the roots [126]. This involves signal transduction from the hypoxic/ anoxic root system to the shoot, and subsequently its perception and conversion into physiological responses, such as drastically reducing energy production through eliminated/ reduced mitochondrial respiration. The energy requirements for survival are produced through fermentation pathways, primarily ethanolic fermentation [127,128].

\subsection{Reactive Oxygen Species (ROS) Homeostasis}

During suboptimal environmental conditions, different pathways are affected differently, which disrupts cellular homeostasis accompanied by the production of reactive oxygen intermediates (ROIs) due to increased electron flow from disrupted pathways to oxygen reduction $[129,130]$. Different studies demonstrated that combined and sequential stresses trigger various ion channels leading to hormonal changes, which in turn, generated unique set of reactive oxygen species (ROS), i.e., $\mathrm{O}_{2}{ }^{-}$and $\mathrm{H}_{2} \mathrm{O}_{2}$ that causes cellular damages termed as 'oxidative stress' (Figure 3) [131,132]. ROS are produced in almost every cellular organelle, primarily having high oxidized metabolic activity (chloroplasts) or high electron flow rates, during numerous enzymatic reactions and are important signaling molecules within the cell and cellular communication in between different cells [41]. Cellular ROS levels are regulated by antioxidant molecules, i.e., carotenoids, tocopherols, alkaloids, phenolic compounds, flavonols, GSH, ascorbate and enzymes i.e., AOX, CAT, APX, SOD, GPX, glutathione reductase, glutathione-S-transferase and peroxidases that keep ROS levels in balance and protects against redox-regulated defense $[110,129,130,133,134]$. It was shown earlier that cytosolic APX1(apx1) or ABA function deficient mutants and ROS-regulated protein PP2Cs (abi-1) are sensitive to combined heat and drought stress response [135-137].

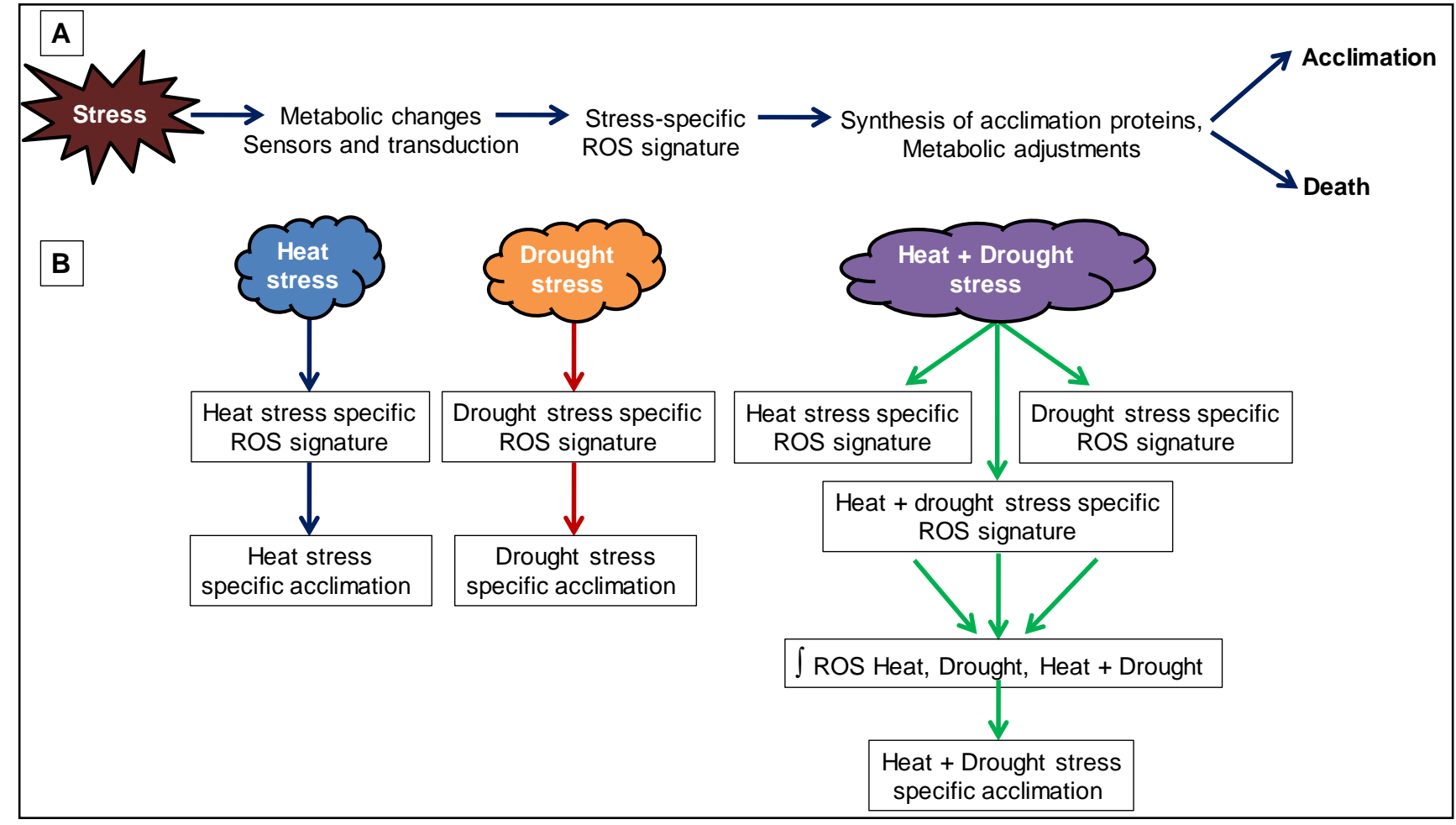

Figure 3. Reactive oxygen species (ROS) signature during abiotic stress combination. (A) Abiotic stress is shown to result in the formation of a ROS signature that mediates plant acclimation or cell death. (B) A combination of two different stresses (heat and drought stress) is shown to generate a ROS signature that is unique to the stress combination and is the result of combining three different ROS signature (ROS signature for heat stress, ROS signature for drought stress and ROS signature generated from the combination of heat + drought stress). 
Previous research has revealed a regulatory network of submergence-induced signal transduction through hormonal regulators, ROS, and ethylene regulating metabolic responses besides morphological adaptations for survival [52]. Post-submergence stress is caused by sudden reoxygenation after prolonged hypoxia/ anoxia and re-illumination, after acclimation to low light under water. This causes electron leakage in membranes and electron-transport chains leading to inactivation of photosystem reaction centers and burst of ROS production [138]. Less ROS-accumulating genotypes display better recovery after de-submergence [52]. The production of ROS singlet oxygen $\left({ }^{1} \mathrm{O}_{2}\right)$ under excessive light inhibits D1 protein synthesis and hampers the repair of photodamaged PSII, dampened carbohydrate replenishment and senescence. Similarly, under heat stress, electrons from $\mathrm{NADH}$ produced by the soluble, membrane-bound complexes at the inner mitochondrial membrane are disrupted or uncoupled $[139,140]$. During stress acclimation, plants undergo metabolite changes that involve reactive oxygen intermediates (ROI) production and defense regulated genes during stress, such as ROI scavenging enzymes and heat shock proteins [141]. Various studies have demonstrated that plants display higher ROS burst and antioxidant enzyme activity under individual and combined cold and salt stress [130] or drought and salinity [142], such as rice [140], Azolla [143], wheat [144], and barrel clover [145]. Previous studies have also shown dehydration and submergence tolerance through ROS detoxification regulatory enzyme and their transcriptional regulation in tobacco, rice, and Arabidopsis [108,139].

\subsection{Multi-Omics Approach: New Potential Key Mechanisms}

Significant developments have been made in plant genomics, particularly contributing to the development of stress tolerant crops. Transcript profiling under individual and combined stresses showed significant differences in plants $[133,146]$, indicating differential regulation of combined and sequential stresses under individual and combined stresses [7]. Yet, little is known about the overlapping stress combinations and their genetic interplay of unique-differentially expressed genes (DEGs) during plant acclimations the well-documented phenomena of "cross tolerance" [32]. Therefore, the major challenge is to develop multiple stress tolerant cultivars with lack of information on physiological and molecular mechanisms. The complex signaling pathways associated with stress sensing and activation of defense and acclimation pathways involve mitogen-activated protein kinase cascades, calcium-regulated proteins, ROI, and cross talk among various transcription factors $[39,147,148]$. Interestingly, different stress conditions can trigger similar stress response pathways $[39,149]$. Various studies have been conducted to delineate the cellular metabolism of crop species, but despite recent advancements in genomics, metabolic adaptations under multiple stresses remain poorly characterized and require a systematic understanding ofhighthroughput "omics" combined within silico metabolic modeling [128].

\subsubsection{Transcriptomics}

Despite the continuous generation of transcriptomic data from various studies, our understanding of plant responses against combined or sequential stress is incomplete. Comparative transcriptomic studies have revealed molecular cross talks due to differential accumulation of both "unique genes" or "shared genes" during individual or combined or sequential stress (Figure 4) $[150,151]$. Shared genes between individual and combined stress have mostly demonstrated the differential expression of transcription factor (TF)-encoding genes, polyamine and primary carbon metabolism related genes and phytohormone pathway-related genes [152]. Comparative transcriptomics in Arabidopsis plants treated with six abiotic stresses (osmotic, oxidative, salinity, drought, heat and cold) and one biotic stress (Botrytis cinerea) revealed upregulation of 3 genes and downregulation of 12 genes under individual stresses and 13 genes commonly upregulated under heat/salinity/osmotic stress/B. cinerea stress, while 29 genes were commonly downregulated [153]. Previous workers have demonstrated that members of MAPK family 
were differentially regulated during various abiotic and biotic stresses and differentially regulate their downstream gene expression and signaling responses [41]. MAPK pathways also show cross talk with ABA signaling pathways, ROS and ethylene [154,155]. In previous studies, the altered expression of various micro-RNAs and their gene regulation in transgenic plants have been observed during various stress experiments $[11,156]$. In addition, $\mathrm{Ca}^{2+}$ ions also play a key role during abiotic stress signaling, where they enter the cell through $\mathrm{Ca}^{2+}$-permeable channels to regulate specific downstream responses, such as protein interactions and stress-responsive gene expression [157].

\section{(A) Transcripts}

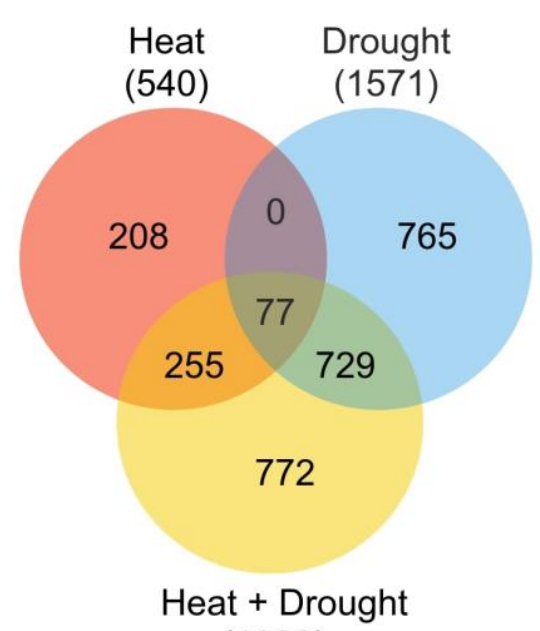

(1833)
(B) Proteins

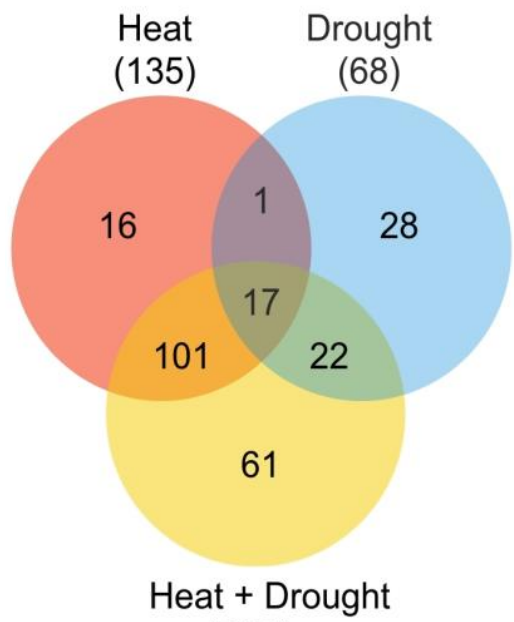

(201)
(C) Metabolites

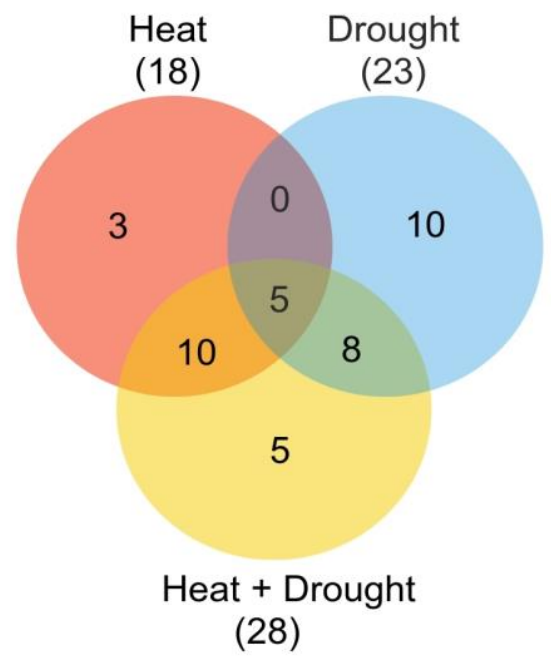

Figure 4. Unique characteristics of multi-omics studies under heat, drought and combined heat + drought stress. Venn diagram showing the overlap between (A) transcripts, (B) proteins, (C) metabolites (up-regulated or down-regulated) during heat or drought stress, or a combination of heat and drought stress. The total number of transcripts or metabolites is indicated in parenthesis. The stress-induced expression was based on a significant linear regression $(p<0.01)$ and a threshold of $\geq 1.5$-fold $\left(\log _{2}\right)$ over control $[17,19]$.

Previous studies on heat and drought stress revealed altered physiological changes that are reflected in their gene expression patterns subjected to combined stress [17]. In wheat, large overlaps were reported in commonly up-regulated or down-regulated genes during individual and combined stress [158]. Similarly, in other plants, the unique transcript profile was observed in response to combined heat and drought stress acclimation [159]. Further, rapid changes in various transcription factor families (DREB, NAC, MYB, bZIP) was observed, which further activated downstream stress response pathways and were coordinated through synergistic or antagonistic interactions of metabolic and hormonal pathways under different abiotic stresses [160].

To improve the productivity of rice in coastal areas, genotypes tolerant to both water stagnation and salinity stress together can improve breeding efficiency [50]. It was reported earlier that submergence tolerance gene SUB1A imparts tolerance only under the vegetative stage, neither in germination nor at the reproductive phases [93]. A polygenic locus encoding two APETALA2/ Ethylene Response Factor (AP2/ERF) DNA binding proteins, SNORKEL1 and SNORKEL 2 (SK1 and SK2) provides an escape response by downregulating brassinosteroid synthesis and promoting gibberellic acid regulated internode elongation in deep-water rice $[106,161]$. In contrast, submergence1A-1 (Sub1A-1) restricts shoot elongation for adaptation and induces alcohol dehydrogenase genes for carbohydrate production [52,162]. A traditional rice cultivar "Baliadhan," with SUB1 QTL is flooding tolerant during reproductive stage more than Swarna and Swarna-Sub1 [51,163]. 
However, cultivar FR13A (Dhalaputia) tolerates flooding even more easily because of long stature [164] and retaining airy zones (gas films) around their leaves for longer durations [51]. These gas films help in maintaining the carbohydrate status and internal aeration in rice during submergence. In contrast, FR13A is susceptible to salinity, but showed similar response during submergence and salinity in coastal areas [165]. It shows that submergence tolerance is independent of submergence inducible genes SUB1B and SUB1C, located at SUB1 locus in rice [51]. SUB1A was also reported to delay chlorophyll and carbohydrate breakdown in aerial tissue under prolonged darkness $[106,166]$ and the loss of function mutants (prt6-1 and ged1) showed starch accumulation in leaves during submergence, providing enhanced survival [167].

During sequential submergence and post-submergence stress, ethylene is produced rapidly and accumulates in the cell membrane. Here, it binds with ethylene receptors and stabilizes ETHYLENE-INSENSITIVE3-LIKE1 (EIL1) and ETHYLENE-INSENSITIVE3 (EIN3) transcription factors and regulates downstream genes leading to a sequential stress response, including leaf hyponasty, shoot elongation, and adventitious root formation $[106,168]$. SUB1A, avoids unnecessary energy consumption due to gibberellin (GA)-mediated elongation of submerged tissues $[37,169,170]$. SUB1A also increases brassinosteroids (BR) production, which enhances SLENDER RICE1 (SLR1, a DELLA protein) accumulation and further bioactive GA degradation [171]. OsETOL1 was found to negatively regulate ACC and ethylene production under drought and inhibits carbohydrate transportation to the developing seeds from leaves, leading to reduced grain filling and spikelet fertility. In contrast, OsETOL1 promotes carbohydrate consumption and energy production during submergence causing leaf elongation [37]. Similarly, sucrosenonfermenting1-related protein kinase1A (SnRK1A), an ortholog of mammalian adenosine monophosphate-activated protein kinase (AMPK) and yeast sucrose nonfermenting1 (SNF1) is reported as a carbohydrate starvation/energy depletion sensor during submergence. Further, trehalose-6-phosphate (T6P) inhibits SnRK1 activity and conversion of T6p into trehalose-6-phosphate phosphatase (TPP7, located at submergence tolerance QTL, qAG-9-2), increases sink strength in coleoptiles and germinating embryos, thereby, improving starch mobilization and seed germination under submergence $[106,172,173]$.

SUB1A was also reported to act as convergence point during sequential drought after de-submergence in rice through detoxification of ROS, and stress-inducible gene expression and prevents reduction of hydraulic conductivity in leaves after de-submergence [108]. Microarray and qPCR studies have shown that ethylene biosynthesis and signaling genes gets suppressed under drought stress and overexpression of homeobox $(\mathrm{HB})$ genes regulated by different clades of HD-Zip type transcription factor, enhanced tolerance against various abiotic stresses [174]. Numerous transcription factors were identified having functional roles in transcriptional regulation under drought stress such as DREB/CBF, ABRE, AREB/ABF, NAC and ERF $[175,176]$. SUB1A induces accumulation of these transcription factors along with SLR1 and SLRL1 in ABA-dependent or ABA-independent manner for providing dehydration tolerance [108].

Salinity and drought alters the ionic and osmotic signal pathways respectively in different crops. Various QTLs and transcription factors have been characterized for salt stress (osmotic and ionic) tolerance during different developmental stages such as NAC [177], PDH45 [178], Saltol [51], Hardy [179], HKT [180], NHX [181,182] in rice and SOS [183] in Brassica. SOS signaling pathway is mostly explored during osmotic stress signaling [184,185], since identification of first two-component phosphorelay system (TCS) osmosensor in plant AHK1 [186]. Heterologous expression of various genes in rice showed better ROS detoxification mechanism and reduce membrane damage during salinity and drought stress such as OsMT [187], OsCPK9 [188], MDCP [189], CrRLKs [41] and TPSP [140]. Similarly, Open Stomata1 (OST1), a member of SNF1-related protein kinases2 (SnRK2) protein kinase family is a central regulator of cold signaling pathway [190] besides ABA dependent stomatal closure during osmotic stress [191]. OST1 phosphorylates BTF3 (Basic Transcription Factor3) and ICE1 (Inducer of CBF expression1) transcription factors, leading to the expression 
of COR (Cold-Regulated) genes [192]. Similar studies have demonstrated that unsaturated triacylglycerols accumulation through Phospholipid: Diacylglycerol Acyltransferase1 (PDAT1) increases membrane fluidity during high temperature [193].

\subsubsection{Proteomics}

Abiotic stress has profound impacts on plant proteomes, which include alterations in their localization, post-transcriptional and post-translational modifications, molecular cross-talks and biochemical interactions. Therefore, proteins shape novel phenotype and altered biological traits under environmental vagaries, which include transcriptional regulation of osmotins, dehydrins, LEA, and NAC transcription factors [194-196]. Various functions of proteins have been reported under individual stress while their response under combined stress is still very less. Different reports have confirmed upregulation of enzyme pathways leading to enhanced accumulation of osmoprotectants under salinity and drought stress [197]. The signaling pathways related to differentially expressed proteins during individual and combined stress responses were reported to be different from each other. Of these, some exclusively responded during individual and combined stress, while few showed similar function during individual and combined stress, such as protein kinases, phosphatases, LEA, dehydrins, osmotins, and HSPs [19]. Osmotic (drought and salinity) stress sensory proteins are mostly localized in the plasma membrane and demonstrate similar response individually but differ during combined stress $[40,198]$. Similar reports were observed during proteomics and western blot analysis in response to combined drought and heat stresses as glycolate oxidases, catalases and dehydrins were up-regulated during drought, while thioredoxin peroxidase is up-regulated during heat stress. However, during combined stress, ascorbate peroxidases were specifically down-regulated, while HSPs, alternative oxidase, glutathione peroxidase, cyclophilin, WRKY, phenylalanine ammonia lyase, and ethylene-responsive element-binding protein were upregulated [199-201].

\subsubsection{Metabolomics}

Climate change has exacerbated the unpredictability and severity of environmental vagaries that are sub-optimal for plant growth and survival. Plant resilience to environmental extremes continuously adjust plant metabolism to regulate growth and development within a highly dynamic, and often, inhospitable environment, as well as after the removal of stress. Numerous inter-connected signaling pathways that regulate metabolic networks revealed differential regulation of physiological and biochemical production of secondary metabolites during abiotic stresses, as well as contribute markedly to antioxidant defense response [202,203]. Unfortunately, previous studies on plant metabolites have been focused on individual stresses [204,205], which were later found to differ during combined and sequential stress response [47]. However, few studies on individual and combined abiotic stress reported some uniquely accumulated metabolites during individual stress such as proline, while few compounds accumulated under combined stress, such as sucrose, maltose, and glucose [17]. Therefore, metabolic plasticity may activate appropriate defense responses to cope with multiple environmental stresses [206]. The metabolite profiling of samples during individual and combined abiotic stresses led to the identification of metabolic markers which were closely related [24].

It was hypothesized that secondary metabolite accumulation and related gene expression during drought and salt stress may stimulate osmotic adjustment [207]. Different stress-inducible metabolic networks and signal transduction pathways are triggered during early and later stages of stress to achieve global metabolic homeostasis [208,209]. This reveals greater crosstalk between the metabolic pathways of individual or combined abiotic stresses during different developmental stages $[24,210,211]$. 


\section{Conclusions and Prospective}

Current studies on plant stress response have mainly been focused on individual stress conducted under laboratory conditions. However, to gain a meaningful understanding of the actual field conditions, combined and sequential stress responses need to be thoroughly studied. Previous studies have revealed that combined and sequential stresses act differently or similarly and evoke distinct networks than their individual counterparts. All individual, combined and sequential stresses changes phytohormone balance and nutrient assimilation pattern leading to oxidative stress, as well asreduced growth and yield. Taken together, the distinctive involvement of various stress-responsive transcripts, proteins and metabolites during individual, combined and sequential stresses, suggest unique cellular defense responses. However, detailed analysis of pathways and associated genes during individual, combined and sequential stresses are largely unpredictable. Emerging information about signal integration and stress-signaling pathways can provide information on gene functions to develop advance breeding programs for tailoring stress tolerant genotypes. Despite major advances in elucidating abiotic sensing mechanisms, the identification of bonafide sensing mechanisms during individual, combined and sequential abiotic stresses will be a boon in delineating cellular signaling pathways and their responses during complex environmental conditions.

Author Contributions: The idea of the study was conceptualized by A.P.; K.A. and R.J. wrote this manuscript; O.P.D., S.L.S.-P. and A.P. participated in the writing and editing of the manuscript. All authors have read and agreed to the published version of the manuscript.

Funding: This research received no external funding.

Institutional Review Board Statement: Not applicable.

Informed Consent Statement: Not applicable.

Data Availability Statement: All data and materials are available upon reasonablerequest from the corresponding author.

Acknowledgments: This research was supported from Department of Biotechnology, Government of India for the joint Indo-NWO project, Indo-US Science and Technology Forum (IUSSTF) through Indo-US Advanced Bioenergy Consortium (IUABC), International Atomic Energy Agency (Vienna), and Institutional Umbrella support over the years under DST-FIST and PURSE; UGC-UPEII, DRS and Networking.

Conflicts of Interest: The authors declare no conflict of interest.

\section{References}

1. Myers, S.S.; Smith, M.R.; Guth, S.; Golden, C.D.; Vaitla, B.; Mueller, N.D.; Dangour, A.D.; Huybers, P. Climate change and global food systems: Potential impacts on food security and undernutrition. Annu. Rev. Public Health 2017, 38, 259-277. [CrossRef]

2. Sinha, P.; Singh, V.K.; Bohra, A.; Kumar, A.; Reif, J.C.; Varshney, R.K. Genomics and breeding innovations for enhancing genetic gain for climate resilience and nutrition traits. Theor. Appl. Genet. 2021. [CrossRef] [PubMed]

3. Meena, K.K.; Sorty, A.M.; Bitla, U.M.; Choudhary, K.; Gupta, P.; Pareek, A.; Singh, D.P.; Prabha, R.; Sahu, P.K.; Gupta, V.K.; et al. Abiotic Stress Responses and Microbe-Mediated Mitigation in Plants: The Omics Strategies. Front. Plant Sci. $2017,8,172$. [CrossRef]

4. Bilal, S.; Shahzad, R.; Imran, M.; Jan, R.; Kim, K.M.; Lee, I.J. Synergistic association of endophytic fungi enhances Glycine max L. resilience to combined abiotic stresses: Heavy metals, high temperature and drought stress. Indust. Crop. Prod. 2020, $143,111931$. [CrossRef]

5. Fawzy, S.; Osman, A.I.; Doran, J.; Rooney, D.W. Strategies for mitigation of climate change: A review. Environ. Chem. Lett. 2020, 30, 1-26. [CrossRef]

6. Zandalinas, S.I.; Fritschi, F.B.; Mittler, R. Global warming, climate change, and environmental pollution: Recipe for a multifactorial stress combination disaster. Trends Plant Sci. 2021, 26, 588-599. [CrossRef]

7. Suzuki, N.; Rivero, R.M.; Shulaev, V.; Blumwald, E.; Mittler, R. Abiotic and biotic stress combinations. New Phytol. 2014, 203, 32-43. [CrossRef] [PubMed]

8. Prasad, P.V.; Pisipati, S.R.; Momčilović, I.; Ristic, Z. Independent and combined effects of high temperature and drought stress during grain filling on plant yield and chloroplast EF-Tu expression in spring wheat. J. Agron. Crop. Sci. 2011, 197, 430-441. [CrossRef] 
9. Rafique, S.; Abdin, M.Z.; Alam, W. Response of combined abiotic stresses on maize (Zea mays L.) inbred lines and interaction among various stresses. Maydica 2020, 64, 8 .

10. Demirel, U.; Morris, W.L.; Ducreux, L.J.; Yavuz, C.; Asim, A.; Tindas, I.; Campbell, R.; Morris, J.A.; Verrall, S.R.; Hedley, P.E.; et al. Physiological, biochemical, and transcriptional responses to single and combined abiotic stress in stress-tolerant and stress-sensitive potato genotypes. Front. Plant Sci. 2020, 11, 169. [CrossRef]

11. Zhang, H.; Sonnewald, U. Differences and commonalities of plant responses to single and combined stresses. Plant J. 2017, 90, 839-855. [CrossRef] [PubMed]

12. Miao, S.L.; Zou, C.B.; Breshears, D.D. Vegetation responses to extreme hydrological events: Sequence matters. Am. Nat. 2009, 173, 113-118. [CrossRef]

13. Tester, M.; Langridge, P. Breeding technologies to increase crop production in a changing world. Science 2013, 327, 818-822. [CrossRef] [PubMed]

14. Rivero, R.M.; Mestre, T.C.; Mittler, R.O.; Rubio, F.; Garcia-Sanchez, F.R.; Martinez, V. The combined effect of salinity and heat reveals a specific physiological, biochemical and molecular response in tomato plants. Plant Cell Environ. 2014, 37, 1059-1073. [CrossRef]

15. Bahuguna, R.N.; Gupta, P.; Bagri, J.; Singh, D.; Dewi, A.K.; Tao, L.; Islam, M.; Sarsu, F.; Singla-Pareek, S.L.; Pareek, A. Forward and reverse genetics approaches for combined stress tolerance in rice. Indian J. Plant Physiol. 2018, 23, 630-646. [CrossRef]

16. Rizhsky, L.; Liang, H.; Mittler, R. The combined effect of drought stress and heat shock on gene expression in tobacco. Plant Physiol. 2002, 130, 1143-1151. [CrossRef]

17. Rizhsky, L.; Liang, H.; Shuman, J.; Shulaev, V.; Davletova, S.; Mittler, R. When defense pathways collide: The response of Arabidopsis to a combination of drought and heat stress. Plant Physiol. 2004, 134, 1683-1696. [CrossRef] [PubMed]

18. Choudhury, F.K.; Rivero, R.M.; Blumwald, E.; Mittler, R. Reactive oxygen species, abiotic stress and stress combination. Plant J. 2017, 90, 856-867. [CrossRef]

19. Zhao, F.; Zhang, D.; Zhao, Y.; Wang, W.; Yang, H.; Tai, F.; Li, C.; Hu, X. The difference of physiological and proteomic changes in maize leaves adaptation to drought, heat, and combined both stresses. Front. Plant Sci. 2016, 7, 1471. [CrossRef] [PubMed]

20. Priya, M.; Dhanker, O.P.; Siddique, K.H.; HanumanthaRao, B.; Nair, R.M.; Pandey, S.; Singh, S.; Varshney, R.K.; Prasad, P.V.; Nayyar, H. Drought and heat stress-related proteins: An update about their functional relevance in imparting stress tolerance in agricultural crops. Theor. Appl. Genet. 2019, 1, 1-32. [CrossRef] [PubMed]

21. Jagadish, S.K.; Muthurajan, R.; Rang, Z.W.; Malo, R.; Heuer, S.; Bennett, J.; Craufurd, P.Q. Spikelet proteomic response to combined water deficit and heat stress in rice (Oryza sativa cv. N22). Rice 2011, 4, 1-11. [CrossRef]

22. Hu, X.; Wu, L.; Zhao, F.; Zhang, D.; Li, N.; Zhu, G.; Li, C.; Wang, W. Phosphoproteomic analysis of the response of maize leaves to drought, heat and their combination stress. Front. Plant Sci. 2015, 6, 298. [CrossRef] [PubMed]

23. Wang, B.; Chen, J.; Chen, L.; Wang, X.; Wang, R.; Ma, L.; Peng, S.; Luo, J.; Chen, Y. Combined drought and heat stress in Camellia oleifera cultivars: Leaf characteristics, soluble sugar and protein contents, and Rubisco gene expression. Trees 2015, 29, 1483-1492. [CrossRef]

24. Obata, T.; Witt, S.; Lisec, J.; Palacios-Rojas, N.; Florez-Sarasa, I.; Yousfi, S.; Araus, J.L.; Cairns, J.E.; Fernie, A.R. Metabolite profiles of maize leaves in drought, heat, and combined stress field trials reveal the relationship between metabolism and grain yield. Plant Physiol. 2015, 169, 2665-2683. [CrossRef]

25. Lawas, L.M.; Li, X.; Erban, A.; Kopka, J.; Jagadish, S.K.; Zuther, E.; Hincha, D.K. Metabolic responses of rice cultivars with different tolerance to combined drought and heat stress under field conditions. Giga Sci. 2019, 8, 1-21. [CrossRef] [PubMed]

26. Craufurd, P.Q.; Peacock, J.M. Effect of heat and drought stress on sorghum (Sorghum bicolor). II. Grain yield. Expt. Agric. 1993, 29, 77-86. [CrossRef]

27. Savin, R.; Nicolas, M.E. Effects of short periods of drought and high temperature on grain growth and starch accumulation of two malting barley cultivars. Funct. Plant Biol. 1996, 23, 201-210. [CrossRef]

28. Heyne, E.G.; Brunson, A.M. Genetic studies of heat and drought tolerance in maize. Agron. J. 1940, 32, 803-814. [CrossRef]

29. Jiang, L.; Dai, T.; Jiang, D.; Cao, W.; Gan, X.; Wei, S. Characterizing physiological N-use efficiency as influenced by nitrogen management in three rice cultivars. Field Crops Res. 2004, 88, 239-250. [CrossRef]

30. Wang, Z.; Huang, B.; Bonos, S.A.; Meyer, W.A. Abscisic acid accumulation in relation to drought tolerance in Kentucky bluegrass. HortScience 2004, 5, 1133-1137. [CrossRef]

31. Loudet, O.; Hasegawa, P.M. Abiotic stress, stress combinations and crop improvement potential. Plant J. 2017, 90, 837-838. [CrossRef]

32. Shaar-Moshe, L.; Blumwald, E.; Peleg, Z. Unique physiological and transcriptional shifts under combinations of salinity, drought, and heat. Plant Physiol. 2017, 174, 421-434. [CrossRef]

33. Tambussi, E.A.; Guiamet, J.J.; Bartoli, C.G. Cross-tolerance to abiotic stress at different levels of organizations: Prospects for scaling-up from laboratory to field. In Priming-Mediated Stress and Cross-Stress Tolerance in Crop Plants; Hossain, M.A., Liu, F., Burritt, D., Fujita, M., Huang, B., Eds.; Academic Press: Cambridge, MA, USA, 2020; pp. 317-327.

34. Sewelam, N.; Brilhaus, D.; Bräutigam, A.; Alseekh, S.; Fernie, A.R.; Maurino, V.G. Molecular plant responses to combined abiotic stresses put a spotlight on unknown and abundant genes. J. Expt. Bot. 2020, 71, 5098-5112. [CrossRef] [PubMed]

35. Hirayama, T.; Shinozaki, K. Research on plant abiotic stress responses in the post-genome era: Past, present and future. Plant J. 2010, 61, 1041-1052. [CrossRef] 
36. Fukao, T.; Xiong, L. Genetic mechanisms conferring adaptation to submergence and drought in rice: Simple or complex? Curr. Opin. Plant Biol. 2013, 16, 196-204. [CrossRef]

37. Du, H.; Wu, N.; Cui, F.; You, L.; Li, X.; Xiong, L. A homolog of ETHYLENE OVERPRODUCER, OsETOL 1, differentially modulates drought and submergence tolerance in rice. Plant J. 2014, 78, 834-849. [CrossRef] [PubMed]

38. Crawford, T.; Karamat, F.; Lehotai, N.; Rentoft, M.; Blomberg, J.; Strand, Å.; Björklund, S. Specific functions for Mediator complex subunits from different modules in the transcriptional response of Arabidopsis thaliana to abiotic stress. Sci. Rep. 2020, 10, 5073. [CrossRef] [PubMed]

39. Pareek, A.; Joshi, R.; Gupta, K.J.; Singla-Pareek, S.L.; Foyer, C. Sensing and signalling in plant stress responses: Ensuring sustainable food security in an era of climate change. New Phytol. 2020, 228, 823-827. [CrossRef]

40. Zandalinas, S.I.; Mittler, R.; Balfagón, D.; Arbona, V.; Gómez-Cadenas, A. Plant adaptations to the combination of drought and high temperatures. Physiol. Plant. 2018, 162, 2-12. [CrossRef] [PubMed]

41. Lamers, J.; van der Meer, T.; Testerink, C. How plants sense and respond to stressful environments. Plant Physiol. 2020, 182, 1624-1635. [CrossRef]

42. Aroca, R.; Porcel, R.; Ruiz-Lozano, J.M. Regulation of root water uptake under abiotic stress conditions. J. Exp. Bot. 2012, 63, 43-57. [CrossRef]

43. Christmann, A.; Weiler, E.W.; Steudle, E.; Grill, E. A hydraulic signal in root-to-shoot signalling of water shortage. Plant J. 2007, 52, 167-174. [CrossRef]

44. Raja, V.; Qadir, S.U.; Alyemeni, M.N.; Ahmad, P. Impact of drought and heat stress individually and in combination on physiobiochemical parameters, antioxidant responses, and gene expression in Solanum lycopersicum. Biotech 2020, 10, 208. [CrossRef] [PubMed]

45. Osakabe, Y.; Osakabe, K.; Shinozaki, K.; Tran, L.S. Response of plants to water stress. Front. Plant Sci. 2014, 13, 86. [CrossRef]

46. Rozema, J.; Flowers, T. Crops for a salinized world. Science 2008, 5, 1478-1480. [CrossRef] [PubMed]

47. Sun, C.; Gao, X.; Fu, J.; Zhou, J.; Wu, X. Metabolic response of maize (Zea mays L.) plants to combined drought and salt stress. Plant Soil 2015, 388, 99-117. [CrossRef]

48. Koevoets, I.T.; Venema, J.H.; Elzenga, J.T.; Testerink, C. Roots withstanding their environment: Exploiting root system architecture responses to abiotic stress to improve crop tolerance. Front. Plant Sci. 2016, 7, 1335. [CrossRef] [PubMed]

49. Lopez, O.R.; Kursar, T.A. Interannual variation in rainfall, drought stress and seedling mortality may mediate monodominance in tropical flooded forests. Oecologia 2007, 154, 35-43. [CrossRef]

50. Pradhan, S.; Babar, M.A.; Robbins, K.; Bai, G.; Mason, R.E.; Khan, J.; Shahi, D.; Avci, M.; Guo, J.; Hossain, M.M.; et al Understanding the genetic basis of spike fertility to improve grain number, harvest index, and grain yield in wheat under high temperature stress environments. Front. Plant Sci. 2019, 10, 1481. [CrossRef] [PubMed]

51. Sarkar, R.K.; Chakraborty, K.; Chattopadhyay, K.; Ray, S.; Panda, D.; Ismail, A.M. Responses of rice to individual and combined stresses of flooding and salinity. In Advances in Rice Research for Abiotic Stress Tolerance; Hasanuzzaman, M., Fujita, M., Nahar, K., Biswas, J., Eds.; Woodhead Publishing: Cambridge, UK, 2019; pp. 281-297.

52. Yeung, E.; Bailey-Serres, J.; Sasidharan, R. After the deluge: Plant revival post-flooding. Trends Plant Sci. 2019, $24,443-454$. [CrossRef]

53. Liu, X.; Huang, M.; Fan, B.; Buckler, E.S.; Zhang, Z. Iterative usage of fixed and random effect models for powerful and efficient genomewide association studies. PLoS Genet. 2016, 12, e1005767. [CrossRef]

54. Dugasa, M.T.; Cao, F.; Ibrahim, W.; Wu, F. Differences in physiological and biochemical characteristics in response to single and combined drought and salinity stresses between wheat genotypes differing in salt tolerance. Physiol. Plant. 2018, 165, 134-143. [CrossRef] [PubMed]

55. Li, P.C.; Yang, X.Y.; Wang, H.M.; Ting, P.A.; Yang, J.Y.; Wang, Y.Y.; Yang, X.U.; Yang, Z.F.; Xu, C.W. Metabolic responses to combined water deficit and salt stress in maize primary roots. J. Integr. Agric. 2021, 20, 109-119. [CrossRef]

56. Vile, D.; Pervent, M.; Belluau, M.; Vasseur, F.; Bresson, J.; Muller, B.; Granier, C.; Simonneau, T. Arabidopsis growth under prolonged high temperature and water deficit: Independent or interactive effects? Plant Cell Environ. 2012, 35, 702-718. [CrossRef] [PubMed]

57. Vescio, R.; Abenavoli, M.R.; Sorgona, A. Single and combined abiotic stress in maize root morphology. Plants 2021, 10, 5. [CrossRef] [PubMed]

58. Sales, C.R.; Ribeiro, R.V.; Silveira, J.A.; Machado, E.C.; Martins, M.O.; Lagôa, A.M. Superoxide dismutase and ascorbate peroxidase improve the recovery of photosynthesis in sugarcane plants subjected to water deficit and low substrate temperature. Plant Physiol. Biochem. 2013, 73, 326-336. [CrossRef]

59. Anderson, J.P.; Badruzsaufari, E.; Schenk, P.M.; Manners, J.M.; Desmond, O.J.; Ehlert, C.; Maclean, D.J.; Ebert, P.R.; Kazan, K. Antagonistic interaction between abscisic acid and jasmonate-ethylene signaling pathways modulates defense gene expression and disease resistance in Arabidopsis. Plant Cell 2004, 16, 3460-3479. [CrossRef]

60. Prasch, C.M.; Sonnewald, U. Simultaneous application of heat, drought, and virus to Arabidopsis plants reveals significant shifts in signalling networks. Plant Physiol. 2013, 162, 1849-1866. [CrossRef] [PubMed]

61. Bandurska, H.; Niedziela, J.; Chadzinikolau, T. Separate and combined responses to water deficit and UV-B radiation. Plant Sci. 2013, 213, 98-105. [CrossRef] [PubMed] 
62. Giraud, E.; Ho, L.H.; Clifton, R.; Carroll, A.; Estavillo, G.; Tan, Y.F.; Howell, K.A.; Ivanova, A.; Pogson, B.J.; Millar, A.H.; et al. The absence of ALTERNATIVE OXIDASE1a in Arabidopsis results in acute sensitivity to combined light and drought stress. Plant Physiol. 2008, 147, 595-610. [CrossRef]

63. Mahmoud, D.; Pandey, R.; Sathee, L.; Dalal, M.; Singh, M.P.; Chinnusamy, V. Regulation of expression of genes associated with nitrate response by osmotic stress and combined osmotic and nitrogen deficiency stress in bread wheat (Triticum aestivum L.). Plant Physiol. Rep. 2020, 25, 200-215. [CrossRef]

64. de Silva, N.D.; Cholewa, E.; Ryser, P. Effects of combined drought and heavy metal stresses on xylem structure and hydraulic conductivity in red maple (Acer rubrum L.). J. Expt. Bot. 2012, 63, 5957-5966. [CrossRef] [PubMed]

65. Alameda, D.; Anten, N.P.; Villar, R. Soil compaction effects on growth and root traits of tobacco depend on light, water regime and mechanical stress. Soil Till. Res. 2012, 120, 121-129. [CrossRef]

66. Meena, S.K.; Pandey, R.; Sharma, S.; Kumar, T.; Singh, M.P.; Dikshit, H.K. Physiological basis of combined stress tolerance to low phosphorus and drought in a diverse set of mungbean germplasm. Agronomy 2021, 11, 99. [CrossRef]

67. Keleş, Y.; Öncel, I. Response of antioxidative defence system to temperature and water stress combinations in wheat seedlings. Plant Sci. 2002, 163, 783-790. [CrossRef]

68. Li, W.; Zhang, C.; Lu, Q.; Wen, X.; Lu, C. The combined effect of salt stress and heat shock on proteome profiling in Suaeda salsa. J. Plant Physiol. 2011, 168, 1743-1752. [CrossRef]

69. Xiong, L.; Yang, Y. Disease resistance and abiotic stress tolerance in rice are inversely modulated by an abscisic acid-inducible mitogen-activated protein kinase. Plant Cell 2003, 15, 745-759. [CrossRef]

70. Kasurinen, A.; Biasi, C.; Holopainen, T.; Rousi, M.; Mäenpää, M.; Oksanen, E. Interactive effects of elevated ozone and temperature on carbon allocation of silver birch (Betula pendula) genotypes in an open-air field exposure. Tree Physiol. 2012, 32, 737-751. [CrossRef]

71. Zhu, Y.; Qian, W.; Hua, J. Temperature modulates plant defense responses through NB-LRR proteins. PLoS Pathog. 2010, 6, e1000844. [CrossRef]

72. Pan, J.; Vicente, A.R.; Martínez, G.A.; Chaves, A.R.; Civello, P.M. Combined use of UV-C irradiation and heat treatment to improve postharvest life of strawberry fruit. J. Sci. Food Agric. 2004, 84, 1831-1838. [CrossRef]

73. Hewezi, T.; Léger, M.; Gentzbittel, L. A comprehensive analysis of the combined effects of high light and high temperature stresses on gene expression in sunflower. Ann. Bot. 2008, 102, 127-140. [CrossRef]

74. Sicher, R.C.; Bunce, J.A. The impact of enhanced atmospheric $\mathrm{CO}_{2}$ concentrations on the responses of maize and soybean to elevated growth temperatures. In Combined Stresses in Plants; Mahalingam, R., Ed.; Springer: Berlin, Germany, 2015 ; pp. 27-48.

75. Szittya, G.; Silhavy, D.; Molnár, A.; Havelda, Z.; Lovas, Á.; Lakatos, L.; Bánfalvi, Z.; Burgyán, J. Low temperature inhibits RNA silencing-mediated defence by the control of siRNA generation. EMBO J. 2003, 22, 633-640. [CrossRef]

76. Haghjou, M.M.; Shariati, M.; Smirnoff, N. The effect of acute high light and low temperature stresses on the ascorbate-glutathione cycle and superoxide dismutase activity in two Dunaliella salina strains. Physiol. Plant. 2009, 135, 272-280. [CrossRef] [PubMed]

77. Amtmann, A.; Troufflard, S.; Armengaud, P. The effect of potassium nutrition on pest and disease resistance in plants. Physiol. Plant. 2008, 133, 682-691. [CrossRef]

78. Srivastava, G.; Kumar, S.; Dubey, G.; Mishra, V.; Prasad, S.M. Nickel and Ultraviolet-B stresses induce differential growth and photosynthetic responses in Pisum sativum L. seedlings. Biol. Trace Elem. Res. 2012, 149, 86-96. [CrossRef]

79. Carvalho, J.M.; Barreto, R.F.; Prado, R.D.; Habermann, E.; Branco, R.B.; Martinez, C.A. Elevated $\mathrm{CO}_{2}$ and warming change the nutrient status and use efficiency of Panicum maximum Jacq. PLoS ONE 2020, 15, e0223937. [CrossRef] [PubMed]

80. Cherif, J.; Mediouni, C.; Ammar, W.B.; Jemal, F. Interactions of zinc and cadmium toxicity in their effects on growth and in antioxidative systems in tomato plants (Solarium lycopersicum). J. Environ. Sci. 2011, 23, 837-844. [CrossRef]

81. Pääkkönen, E.; Vahala, J.; Pohjola, M.; Holopainen, T.; Kärenlampi, L. Physiological, stomatal and ultrastructural ozone responses in birch (Betula pendula Roth.) are modified by water stress. Plant Cell Environ. 1998, 21, 671-684. [CrossRef]

82. Löw, M.; Herbinger, K.; Nunn, A.J.; Häberle, K.H.; Leuchner, M.; Heerdt, C.; Werner, H.; Wipfler, P.; Pretzsch, H.; Tausz, M.; et al. Extraordinary drought of 2003 overrules ozone impact on adult beech trees (Fagus sylvatica). Trees 2006, 20, 539-548. [CrossRef]

83. Iyer, N.J.; Tang, Y.; Mahalingam, R. Physiological, biochemical and molecular responses to a combination of drought and ozone in Medicago truncatula. Plant Cell Environ. 2013, 36, 706-720. [CrossRef]

84. Brouder, S.M.; Volenec, J.J. Impact of climate change on crop nutrient and water use efficiencies. Physiol. Plant. 2008, 133, 705-724. [CrossRef]

85. Martorello, A.Q.; Fernandez, M.E.; Monterubbianesi, M.G.; Colabelli, M.N.; Laclau, P.; Gyenge, J.E. Effect of combined stress (salinity+ hypoxia) and auxin rooting hormone addition on morphology and growth traits in six Salix spp. clones. New For. 2020, 51, 61-80. [CrossRef]

86. Pérez-López, U.; Miranda-Apodaca, J.; Lacuesta, M.; Mena-Petite, A.; Muñoz-Rueda, A. Growth and nutritional quality improvement in two differently pigmented lettuce cultivars grown under elevated $\mathrm{CO}_{2}$ and/or salinity. Sci. Hort. 2015, 195, 56-66. [CrossRef]

87. Martinez-Ballesta, M.D.; Bastías, E.; Zhu, C.; Schäffner, A.R.; González-Moro, B.; González-Murua, C.; Carvajal, M. Boric acid and salinity effects on maize roots. Response of aquaporins ZmPIP1 and ZmPIP2, and plasma membrane H+-ATPase, in relation to water and nutrient uptake. Physiol. Plant. 2008, 132, 479-490. [CrossRef] [PubMed] 
88. Bowler, C.; Fluhr, R. The role of calcium and activated oxygens as signals for controlling cross-tolerance. Trends Plant Sci. 2000, 5, 241-246. [CrossRef]

89. Britton, H.C.; Draper, M.; Talmadge, J.E. Antimicrobial efficacy of aqueous ozone in combination with short chain fatty acid buffers. Infect. Preven. Pract. 2020, 2, 100032. [CrossRef]

90. Magbanua, B.S., Jr.; Savant, G.; Truax, D.D. Combined ozone and ultraviolet inactivation of Escherichia coli. J. Environ. Sci. Health A Tox. Hazard Subst. Environ. Eng. 2006, 41, 1043-1055. [CrossRef]

91. Ainsworth, E.A.; Rogers, A.; Leakey, A.D. Targets for crop biotechnology in a future high- $\mathrm{CO}_{2}$ and high-O 3 world. Plant Physiol. 2008, 147, 13-19. [CrossRef]

92. Mittler, R. Abiotic stress, the field environment and stress combination. Trends Plant Sci. 2006, 11, 15-19. [CrossRef]

93. Sarkar, R.K.; Reddy, J.N.; Sharma, S.G.; Ismail, A.M. Physiological basis of submergence tolerance in rice and implications for crop improvement. Curr Sci. 2006, 91, 899-906.

94. Loka, D.A.; Oosterhuis, D.M.; Baxevanos, D.; Noulas, C.; Hu, W. Single and combined effects of heat and water stress and recovery on cotton (Gossypium hirsutum L.) leaf physiology and sucrose metabolism. Plant Physiol. Biochem. 2020, 148, 166-179. [CrossRef]

95. Anjum, S.A.; Tanveer, M.; Ashraf, U.; Hussain, S.; Shahzad, B.; Khan, I.; Wang, L. Effect of progressive drought stress on growth, leaf gas exchange, and antioxidant production in two maize cultivars. Environ. Sci. Pollut. Res. 2016, 23, 17132-17141. [CrossRef]

96. Hussain, H.A.; Hussain, S.; Khaliq, A.; Ashraf, U.; Anjum, S.A.; Men, S.; Wang, L. Chilling and drought stresses in crop plants: Implications, cross talk, and potential management opportunities. Front. Plant Sci. 2018, 9, 393. [CrossRef]

97. Alghabari, F.; Ihsan, M.Z.; Hussain, S.; Aishia, G.; Daur, I. Effect of Rht alleles on wheat grain yield and quality under high temperature and drought stress during booting and anthesis. Environ. Sci. Pollut. Res. 2015, 22, 15506-15515. [CrossRef] [PubMed]

98. Alghabari, F.; Ihsan, M.Z.; Khaliq, A.; Hussain, S.; Daur, I.; Fahad, S.; Nasim, W. Gibberellin-sensitive Rht alleles confer tolerance to heat and drought stresses in wheat at booting stage. J. Cereal Sci. 2016, 70, 72-78. [CrossRef]

99. Cairns, J.E.; Crossa, J.; Zaidi, P.H.; Grudloyma, P.; Sanchez, C.; Araus, J.L.; Thaitad, S.; Makumbi, D.; Magorokosho, C.; Bänziger, M.; et al. Identification of drought, heat, and combined drought and heat tolerant donors in maize. Crop Sci. 2013, 53, 1335-1346. [CrossRef]

100. Fahad, S.; Bajwa, A.A.; Nazir, U.; Anjum, S.A.; Farooq, A.; Zohaib, A.; Sadia, S.; Nasim, W.; Adkins, S.; Saudm, S.; et al. Crop production under drought and heat stress: Plant responses and management options. Front. Plant Sci. 2017, 8, 1147. [CrossRef]

101. Król, A. The Growth and Water Uptake by Yellow Seed and Black Seed Rape Depending on the State of Soil Compaction. Ph.D. Thesis, Bohdan Dobrzanski Institute of Agrophysics, PAS, Lublin, Poland, 2013.

102. Hussain, H.A.; Men, S.; Hussain, S.; Chen, Y.; Ali, S.; Zhang, S.; Zhang, K.; Li, Y.; Xu, Q.; Liao, C.; et al. Interactive effects of drought and heat stresses on morpho-physiological attributes, yield, nutrient uptake and oxidative status in maize hybrids. Sci. Rep. 2019, 9, 3890. [CrossRef] [PubMed]

103. Sattar, A.; Sher, A.; Ijaz, M.; Ul-Allah, S.; Rizwan, M.S.; Hussain, M.; Jabran, K.; Cheema, M.A. Terminal drought and heat stress alter physiological and biochemical attributes in flag leaf of bread wheat. PLoS ONE 2020, 15, e0232974. [CrossRef] [PubMed]

104. Kadam, N.N.; Yin, X.; Bindraban, P.S.; Struik, P.C.; Jagadish, K.S. Does morphological and anatomical plasticity during the vegetative stage make wheat more tolerant of water deficit stress than rice? Plant Physiol. 2015, 167, 1389-1401. [CrossRef]

105. Voesenek, L.A.; Bailey-Serres, J. Flood adaptive traits and processes: An overview. New Phytol. 2015, 206, 57-73. [CrossRef]

106. Tamang, B.G.; Fukao, T. Plant adaptation to multiple stresses during submergence and following desubmergence. Int. J. Mol. Sci. 2015, 16, 30164-30180. [CrossRef] [PubMed]

107. Bailey-Serres, J.; Voesenek, L.A. Flooding stress: Acclimations and genetic diversity. Annu. Rev. Plant Biol. 2008, 59, 313-339. [CrossRef]

108. Fukao, T.; Yeung, E.; Bailey-Serres, J. The submergence tolerance regulator SUB1A mediates crosstalk between submergence and drought tolerance in rice. Plant Cell 2011, 23, 412-427. [CrossRef]

109. Zheng, C.; Jiang, D.; Liu, F.; Dai, T.; Jing, Q.; Cao, W. Effects of salt and waterlogging stresses and their combination on leaf photosynthesis, chloroplast ATP synthesis, and antioxidant capacity in wheat. Plant Sci. 2009, 176, 575-582. [CrossRef]

110. Chojak-Kozniewska, J.; Kuzniak, E.; Zimny, J. The effects of combined abiotic and pathogen stress in plants: Insights from salinity and Pseudomonas syringaepvlachrymans interaction in cucumber. Front. Plant Sci. 2018, 9, 1691. [CrossRef] [PubMed]

111. Cornic, G. Drought stress inhibits photosynthesis by decreasing stomatal aperture-not by affecting ATP synthesis. Trends Plant Sci. 2020, 5, 187-188. [CrossRef]

112. Zhou, X.; Wan, S.; Luo, Y. Source components and interannual variability of soil $\mathrm{CO}_{2}$ efflux under experimental warming and clipping in a grassland ecosystem. Glob. Chang. Biol. 2007, 13, 761-775.

113. Radhakrishna, N.K.; Chenniappan, V.; Dhashnamurthi, V. Combined effects of drought and moderately high temperature on the photosynthesis, PS II photochemistry and yield traits in rice (Oryza sativa L.). Indian J. Plant Physiol. 2018, 23, 408-415. [CrossRef]

114. Yin, Y.; Li, S.; Liao, W.; Lu, Q.; Wen, X.; Lu, C. Photosystem II photochemistry, photo inhibition, and the xanthophyll cycle in heat-stressed rice leaves. J. Plant Physiol. 2010, 167, 959-966. [CrossRef] [PubMed]

115. Dusenge, M.E.; Duarte, A.G.; Way, D.A. Plant carbon metabolism and climate change: Elevated $\mathrm{CO}_{2}$ and temperature impacts on photosynthesis, photorespiration and respiration. New Phytol. 2019, 221, 32-49. [CrossRef] [PubMed]

116. Ristic, Z.; Bukovnik, U.; Momčilović, I.; Fu, J.; Prasad, P.V. Heat-induced accumulation of chloroplast protein synthesis elongation factor, EF-Tu, in winter wheat. J. Plant Physiol. 2008, 165, 192-202. [CrossRef] [PubMed] 
117. Steponkus, P.L. Role of the plasma membrane in freezing injury and cold acclimation. Annu. Rev. Plant Physiol. 1984, 35, 543-584. [CrossRef]

118. Hetherington, S.E.; He, J.; Smillie, R.M. Photoinhibition at low temperature in chilling-sensitive and-resistant plants. Plant Physiol. 1989, 90, 1609-1615. [CrossRef]

119. Haldimann, P.; Fracheboud, Y.; Stamp, P. Photosynthetic performance and resistance to photoinhibition of Zea mays L. leaves grown at sub-optimal temperature. Plant Cell Environ. 1996, 19, 85-92. [CrossRef]

120. Bryla, D.R.; Bouma, T.J.; Hartmond, U.; Eissenstat, D.M. Influence of temperature and soil drying on respiration of individual roots in citrus: Integrating greenhouse observations into a predictive model for the field. Plant Cell Environ. 2001, 24, 781-790. [CrossRef]

121. Wardlaw, I.F.; Dawson, I.A.; Munibi, P. The tolerance of wheat to hight temperatures during reproductive growth. 2. Grain development. Aust. J. Agricult. Res. 1989, 40, 15-24. [CrossRef]

122. Xu, Z.Z.; Zhou, G.S. Effects of water stress and high nocturnal temperature on photosynthesis and nitrogen level of a perennial grass Leymus chinensis. Plant Soil 2005, 269, 131-139. [CrossRef]

123. Xu, Z.Z.; Zhou, G.S. Combined effects of water stress and high temperature on photosynthesis, nitrogen metabolism and lipid peroxidation of a perennial grass Leymus chinensis. Planta 2006, 224, 1080-1090. [CrossRef]

124. Loka, D.A.; Oosterhuis, D.M.; Ritchiem, G.L. Water-deficit stress in cotton. Stress Physiol. Cotton 2011, 7, 37-72.

125. Paudel, I.; Cohen, S.; Shlizerman, L.; Jaiswal, A.K.; Shaviv, A.; Sadka, A. Reductions in root hydraulic conductivity in response to clay soil and treated waste water are related to PIPs down-regulation in Citrus. Sci. Rep. 2017, 7, 15429. [CrossRef]

126. Pedersen, O.; Perata, P.; Voesenek, L.A. Flooding and low oxygen responses in plants. Funct. Plant Biol. 2017, 44, iii-vi. [CrossRef]

127. Magneschi, L.; Perata, P. Rice germination and seedling growth in the absence of oxygen. Ann. Bot. 2009, 103, 181-196. [CrossRef]

128. Lakshmanan, M.; Zhang, Z.; Mohanty, B.; Kwon, J.Y.; Choi, H.Y.; Nam, H.J.; Kim, D.I.; Lee, D.Y. Elucidating rice cell metabolism under flooding and drought stresses using flux-based modeling and analysis. Plant Physiol. 2013, 162, 2140-2150. [CrossRef]

129. Joshi, R.; Chinnusamy, V. Antioxidant enzymes: Defense against high temperature stress. In Oxidative Damage to Plants; Ahmad, P., Ed.; Academic Press: Cambridge, MA, USA, 2014; pp. 369-396.

130. Hasanuzzaman, M.; Bhuyan, M.H.; Zulfiqar, F.; Raza, A.; Mohsin, S.M.; Mahmud, J.A.; Fujita, M.; Fotopoulos, V. Reactive oxygen species and antioxidant defense in plants under abiotic stress: Revisiting the crucial role of a universal defense regulator. Antioxidants 2020, 9, 681. [CrossRef]

131. Mittler, R. Oxidative stress, antioxidants and stress tolerance. Trends Plant Sci. 2002, 7, 405-410. [CrossRef]

132. Muthuramalingam, P.; Krishnan, S.R.; Pothiraj, R.; Ramesh, M. Global transcriptome analysis of combined abiotic stress signaling genes unravels key players in Oryza sativa L.: An in silico approach. Front. Plant Sci. 2017, 8, 759. [CrossRef] [PubMed]

133. Rasmussen, S.; Barah, P.; Suarez-Rodriguez, M.C.; Bressendorff, S.; Friis, P.; Costantino, P.; Bones, A.M.; Nielsen, H.B.; Mundy, J. Transcriptome responses to combinations of stresses in Arabidopsis. Plant Physiol. 2013, 161, 1783-1794. [CrossRef] [PubMed]

134. Shigeoka, S.; Maruta, T. Cellular redox regulation, signaling, and stress response in plants. Biosci. Biotechnol. Biochem. 2014, 78, 1457-1470. [CrossRef] [PubMed]

135. Sekmen, A.H.; Ozgur, R.; Uzilday, B.; Turkan, I. Reactive oxygen species scavenging capacities of cotton (Gossypium hirsutum) cultivars under combined drought and heat induced oxidative stress. Environ. Exp. Bot. 2014, 99, 141-149. [CrossRef]

136. Zandalinas, S.I.; Balfagon, D.; Arbona, V.; Gomez-Cadenas, A.; Inupakutika, M.A.; Mittler, R. ABA is required for the accumulation of APX1 and MBF1c during a combination of water deficit and heat stress. J. Exp. Bot. 2016, 67, 5381-5390. [CrossRef]

137. Postiglione, A.E.; Muday, G.K. The role of ROS homeostasis in ABA-induced guard cell signaling. Front. Plant Sci. 2020, 11, 968. [CrossRef]

138. Yeung, E.; van Veen, H.; Vashisht, D.; Paiva, A.L.; Hummel, M.; Rankenberg, T.; Steffens, B.; Steffen-Heins, A.; Sauter, M.; de Vries, M.; et al. A stress recovery signaling network for enhanced flooding tolerance in Arabidopsis thaliana. Proc. Natl. Acad. Sci. USA 2018, 115, E6085-E6094. [CrossRef] [PubMed]

139. Davidson, J.F.; Schiestl, R.H. Cytotoxic and genotoxic consequences of heat stress are dependent on the presence of oxygen in Saccharomyces cerevisiae. J. Bacteriol. 2001, 183, 4580-4597. [CrossRef] [PubMed]

140. Joshi, R.; Sahoo, K.K.; Singh, A.K.; Anwar, K.; Pundir, P.; Gautam, R.K.; Krishnamurthy, S.L.; Sopory, S.K.; Pareek, A.; SinglaPareek, S.L. Enhancing trehalose biosynthesis improves yield potential in marker-free transgenic rice under drought, saline, and sodic conditions. J. Expt. Bot. 2020, 71, 653-668. [CrossRef] [PubMed]

141. Thirumalaikumar, V.P.; Gorka, M.; Schulz, K.; Masclaux-Daubresse, C.; Sampathkumar, A.; Skirycz, A.; Vierstra, R.D.; Balazadeh, S. Selective autophagy regulates heat stress memory in Arabidopsis by NBR1-mediated targeting of HSP90 and ROF1. Autophagy 2020. [CrossRef] [PubMed]

142. Ibrahim, W.; Zhu, Y.M.; Chen, Y.; Qiu, C.W.; Zhu, S.; Wu, F. Genotypic differences in leaf secondary metabolism, plant hormones and yield under alone and combined stress of drought and salinity in cotton genotypes. Physiol. Plant. 2019, 165, 343-355. [CrossRef]

143. Masood, A.; Shah, N.A.; Zeeshan, M.; Abraham, G. Differential response of antioxidant enzymes to salinity stress in two varieties of Azolla (Azolla pinnata and Azolla filiculoides). Environ. Exp. Bot. 2006, 58, 216-222. [CrossRef]

144. Liang, Y.; Zhu, J.; Li, Z.; Chu, G.; Ding, Y.; Zhang, J.; Sun, W. Role of silicon in enhancing resistance to freezing stress in two contrasting winter wheat cultivars. Environ. Expt. Bot. 2008, 64, 286-294. [CrossRef] 
145. Mhadhbi, H.; Fotopoulos, V.; Mylona, P.V.; Jebara, M.; Aouani, M.E.; Polidoros, A.N. Alternative oxidase 1 (Aox1) gene expression in roots of Medicago truncatula is a genotype-specific component of salt stress tolerance. J. Plant Physiol. 2013, 170, 111-114. [CrossRef]

146. Bahuguna, R.N.; Jagadish, K.S. Temperature regulation of plant phenological development. Environ. Exp. Bot. 2015, 111, 83-90. [CrossRef]

147. Pareek, A.; Khurana, A.K.; Sharma, A.; Kumar, R. An overview of signaling regulons during cold stress tolerance in plants. Curr. Genom. 2017, 18, 498-511. [CrossRef]

148. Saijo, Y.; Loo, E.P. Plant immunity in signal integration between biotic and abiotic stress responses. New Phytol. 2020, $225,87-104$. [CrossRef]

149. Hotamisligil, G.S.; Davis, R.J. Cell signaling and stress responses. Cold Spring Harb. Perspect. Biol. 2016, 8, a006072. [CrossRef] [PubMed]

150. Zhang, N.; Zhou, S.; Yang, D.; Fan, Z. Revealing shared and distinct genes responding to JA and SA signaling in arabidopsis by meta-analysis. Front. Plant Sci. 2020, 11, 908. [CrossRef]

151. Shailani, A.; Joshi, R.; Singla-Pareek, S.L.; Pareek, A. Stacking for future: Pyramiding genes to improve drought and salinity tolerance in rice. Physiol. Plant. 2020, 172, 1352-1362. [CrossRef] [PubMed]

152. Dixit, S.; Singh, U.M.; Abbai, R.; Ram, T.; Singh, V.K.; Paul, A.; Virk, P.S.; Kumar, A. Identification of genomic region (s) responsible for high iron and zinc content in rice. Sci. Rep. 2019, 9, 8136. [CrossRef] [PubMed]

153. Sham, A.; Moustafa, K.; Al-Ameri, S.; Al-Azzawi, A.; Iratni, R.; AbuQamar, S. Identification of Arabidopsis candidate genes in response to biotic and abiotic stresses using comparative microarrays. PLoS ONE 2015, 10, e0125666. [CrossRef]

154. Chang, R.; Jang, C.J.H.; Branco-Price, C.; Nghiem, P.; Bailey-Serres, J. Transient MPK6 activation in response to oxygen deprivation and reoxygenation is mediated by mitochondria and aids seedling survival in Arabidopsis. Plant Mol. Biol. 2012, 78, 109-122. [CrossRef]

155. Zhang, S. Mitogen-activated protein kinase cascades in plant signaling. Ann. Plant Rev. 2018, 15, 100-136.

156. Zhang, B. MicroRNA: A new target for improving plant tolerance to abiotic stress. J. Expt. Bot. 2015, 66, 1749-1761. [CrossRef] [PubMed]

157. Manishankar, P.; Wang, N.; Köster, P.; Alatar, A.A.; Kudla, J. Calcium signaling during salt stress and in the regulation of ion homeostasis. J. Expt. Bot. 2018, 69, 4215-4226. [CrossRef] [PubMed]

158. Liu, Z.; Xin, M.; Qin, J.; Peng, H.; Ni, Z.; Yao, Y.; Sun, Q. Temporal transcriptome profiling reveals expression partitioning of homeologous genes contributing to heat and drought acclimation in wheat (Triticum aestivum L.). BMC Plant Biol. 2015, 15, 1-20. [CrossRef] [PubMed]

159. Xu, Y.; Huang, B. Comparative transcriptomic analysis reveals common molecular factors responsive to heat and drought stress in Agrostis stolonifera. Sci. Rep. 2018, 8, 15181. [CrossRef] [PubMed]

160. Jangale, B.L.; Chaudhari, R.S.; Azeez, A.; Sane, P.V.; Sane, A.P.; Krishna, B. Independent and combined abiotic stresses affect the physiology and expression patterns of DREB genes differently in stress-susceptible and resistant genotypes of banana. Physiol. Plant. 2019, 165, 303-318. [CrossRef] [PubMed]

161. Patil, V.; McDermott, H.I.; McAllister, T.; Cummins, M.; Silva, J.C.; Mollison, E.; Meikle, R.; Morris, J.; Hedley, P.E.; Waugh, R.; et al. APETALA2 control of barley internode elongation. Development 2019, 146, dev170373. [CrossRef]

162. Alam, R.; Hummel, M.; Yeung, E.; Locke, A.M.; Ignacio, J.C.I.; Baltazar, M.D.; Jia, Z.; Ismail, A.M.; Septiningsih, E.M.; Bailey-Serres, J. Flood resilience loci SUBMERGENCE 1 and ANAEROBIC GERMINATION 1 interact in seedlings established underwater. Plant Direct 2020, 4, e00240. [CrossRef]

163. Ray, A.; Panda, D.; Sarkar, R.K. Can rice cultivar with submergence tolerant quantitative trait locus (SUB1) manage submergence stress better during reproductive stage? Arch. Agron. Soil Sci. 2017, 63, 998-1008. [CrossRef]

164. Xu, K.; Mackill, D.J. A major locus for submergence tolerance mapped on rice chromosome 9. Mol. Breed. 1996, 2, 219-224. [CrossRef]

165. Sarkar, R.K.; Ray, A. Submergence-tolerant rice withstands complete submergence even in saline water: Probing through chlorophyll a fluorescence induction OJIP transients. Photosynthetica 2016, 54, 275-287. [CrossRef]

166. Fukao, T.; Yeung, E.; Bailey-Serres, J. The submergence tolerance gene SUB1A delays leaf senescence under prolonged darkness through hormonal regulation in rice. Plant Physiol. 2012, 160, 1795-1807. [CrossRef] [PubMed]

167. Riber, W.; Müller, J.T.; Visser, E.J.; Sasidharan, R.; Voesenek, L.A.; Mustroph, A. The greening after extended darkness1 is an $\mathrm{N}$-end rule pathway mutant with high tolerance to submergence and starvation. Plant Physiol. 2015, 167, 1616-1629. [CrossRef]

168. Dolgikh, V.A.; Pukhovaya, E.M.; Zemlyanskaya, E.V. Shaping ethylene response: The role of EIN3/EIL1 transcription factors. Front. Plant Sci. 2019, 10, 1030. [CrossRef]

169. Jung, S.C.; Martinez-Medina, A.; Lopez-Raez, J.A.; Pozo, M.J. Mycorrhiza-induced resistance and priming of plant defenses. J Chem Eco. 2010, 38, 651-664. [CrossRef]

170. Bailey-Serres, J.; Voesenek, L.A. Life in the balance: A signaling network controlling survival of flooding. Curr. Opin. Plant Biol. 2010, 13, 489-494. [CrossRef]

171. Schmitz, A.J.; Folsom, J.J.; Jikamaru, Y.; Ronald, P.; Walia, H. SUB1A-mediated submergence tolerance response in rice involves differential regulation of the brassinosteroid pathway. New Phytol. 2013, 198, 1060-1070. [CrossRef] [PubMed] 
172. Delatte, T.L.; Sedijani, P.; Kondou, Y.; Matsui, M.; de Jong, G.J.; Somsen, G.W.; Wiese-Klinkenberg, A.; Primavesi, L.F.; Paul, M.J.; Schluepmann, H. Growth arrest by trehalose-6-phosphate: An astonishing case of primary metabolite control over growth by way of the SnRK1 signaling pathway. Plant Physiol. 2011, 157, 160-174. [CrossRef] [PubMed]

173. Kretzschmar, T.; Pelayo, M.A.; Trijatmiko, K.R.; Gabunada, L.F.; Alam, R.; Jimenez, R.; Mendioro, M.S.; Slamet-Loedin, I.H.; Sreenivasulu, N.; Bailey-Serres, J.; et al. A trehalose-6-phosphate phosphatase enhances anaerobic germination tolerance in rice. Nat. Plant. 2015, 1, 1-5. [CrossRef]

174. Zhao, S.; Gao, H.; Jia, X.; Wang, H.; Ke, M.; Ma, F. The HD-Zip I transcription factor MdHB-7 regulates drought tolerance in transgenic apple (Malus domestica). Environ. Expt. Bot. 2020, 180, 104246. [CrossRef]

175. Singh, D.; Laxmi, A. Transcriptional regulation of drought response: A tortuous network of transcriptional factors. Front. Plant Sci. 2015, 6, 895. [CrossRef]

176. Joshi, R.; Wani, S.H.; Singh, B.; Bohra, A.; Dar, Z.A.; Lone, A.A.; Pareek, A.; Singla-Pareek, S.L. Transcription factors and plants response to drought stress: Current understanding and future directions. Front. Plant Sci. 2016, 7, 1029. [CrossRef]

177. Parvin, S.; Biswas, S.; Razzaque, S.; Haque, T.; Elias, S.M.; Tammi, R.S.; Seraj, Z.I. Salinity and drought tolerance conferred by in planta transformation of SNAC1 transcription factor into a high-yielding rice variety of Bangladesh. Acta Physiol. Plant. 2015, 37, 68. [CrossRef]

178. Amin, M.; Elias, S.M.; Hossain, A.; Ferdousi, A.; Rahman, M.S.; Tuteja, N.; Seraj, Z.I. Over-expression of a DEAD-box helicase, PDH45, confers both seedling and reproductive stage salinity tolerance to rice (Oryza sativa L.). Mol. Breed. 2012, 30, 345-354. [CrossRef]

179. Karaba, A.; Dixit, S.; Greco, R.; Aharoni, A.; Trijatmiko, K.R.; Marsch-Martinez, N.; Krishnan, A.; Nataraja, K.N.; Udayakumar, M.; Pereira, A. Improvement of water use efficiency in rice by expression of HARDY, an Arabidopsis drought and salt tolerance gene. Proc. Natl. Acad. Sci. USA 2007, 104, 15270-15275. [CrossRef]

180. Ren, Z.H.; Gao, J.P.; Li, L.G.; Cai, X.L.; Huang, W.; Chao, D.Y.; Zhu, M.Z.; Wang, Z.Y.; Luan, S.; Lin, H.X. A rice quantitative trait locus for salt tolerance encodes a sodium transporter. Nat. Genet. 2005, 37, 1141-1146. [CrossRef] [PubMed]

181. Fukuda, A.; Nakamura, A.; Tagiri, A.; Tanaka, H.; Miyao, A.; Hirochika, H.; Tanaka, Y. Function, intracellular localization and the importance in salt tolerance of a vacuolar $\mathrm{Na}^{+} / \mathrm{H}^{+}$antiporter from rice. Plant Cell Physiol. 2004, 45, 146-159. [CrossRef] [PubMed]

182. Rajagopal, D.; Agarwal, P.; Tyagi, W.; Singla-Pareek, S.L.; Reddy, M.K.; Sopory, S.K. Pennisetum glaucum $\mathrm{Na}^{+} / \mathrm{H}^{+}$antiporter confers high level of salinity tolerance in transgenic Brassica juncea. Mol. Breed. 2007, 19, 137-151. [CrossRef]

183. Kaur, C.; Kumar, G.; Kaur, S.; Ansari, M.W.; Pareek, A.; Sopory, S.K.; Singla-Pareek, S.L. Molecular cloning and characterization of salt overly sensitive gene promoter from Brassica juncea (BjSOS2). Mol. Biol. Rep. 2015, 42, 1139-1148. [CrossRef]

184. Ji, H.; Pardo, J.M.; Batelli, G.; Van Oosten, M.J.; Bressan, R.A.; Li, X. The Salt Overly Sensitive (SOS) pathway: Established and emerging roles. Mol. Plant 2013, 6, 275-286. [CrossRef]

185. Nutan, K.K.; Kumar, G.; Singla-Pareek, S.L.; Pareek, A. A salt overly sensitive pathway member from Brassica juncea BjSOS3 can functionally complement $\triangle$ Atsos3 in Arabidopsis. Curr. Genom. 2018, 19, 60. [CrossRef] [PubMed]

186. Sharan, A.; Soni, P.; Nongpiur, R.C.; Singla-Pareek, S.L.; Pareek, A. Mapping the 'Two-component system' network in rice. Sci. Rep. 2017, 7, 9287. [CrossRef]

187. Kumar, G.; Kushwaha, H.R.; Panjabi-Sabharwal, V.; Kumari, S.; Joshi, R.; Karan, R.; Mittal, S.; Pareek, S.L.; Pareek, A. Clustered metallothionein genes are co-regulated in rice and ectopic expression of OsMT1e-Pconfers multiple abiotic stress tolerance in tobacco via ROS scavenging. BMC Plant Biol. 2012, 12, 107. [CrossRef]

188. Wei, S.; Hu, W.; Deng, X.; Zhang, Y.; Liu, X.; Zhao, X.; Luo, Q.; Jin, Z.; Li, Y.; Zhou, S.; et al. A rice calcium-dependent protein kinase OsCPK9 positively regulates drought stress tolerance and spikelet fertility. BMC Plant Biol. 2014, 14, 133. [CrossRef]

189. Kushwaha, H.R.; Joshi, R.; Pareek, A.; Singla-Pareek, S.L. MATH-domain family shows response toward abiotic stress in Arabidopsis and rice. Front. Plant Sci. 2016, 7, 923. [CrossRef] [PubMed]

190. Ding, Y.; Lv, J.; Shi, Y.; Gao, J.; Hua, J.; Song, C.; Gong, Z.; Yang, S. EGR 2 phosphatase regulates OST 1 kinase activity and freezing tolerance in Arabidopsis. EMBO J. 2019, 38, e99819. [CrossRef]

191. Munemasa, S.; Hirao, Y.; Tanami, K.; Mimata, Y.; Nakamura, Y.; Murata, Y. Ethylene inhibits methyl Jasmonate-Induced stomatal closure by modulating guard cell Slow-Type anion channel activity via the OPEN STOMATA 1/SnRK2. 6 Kinase-Independent Pathway in Arabidopsis. Plant Cell Physiol. 2019, 60, 2263-2271. [CrossRef]

192. Ding, Y.; Jia, Y.; Shi, Y.; Zhang, X.; Song, C.; Gong, Z.; Yang, S. OST 1-mediated BTF 3L phosphorylation positively regulates CBFs during plant cold responses. EMBO J. 2018, 37, e98228. [CrossRef] [PubMed]

193. Mueller, S.P.; Unger, M.; Guender, L.; Fekete, A.; Mueller, M.J. Phospholipid: Diacylglycerol acyltransferase-mediated triacylglyerol synthesis augments basal thermotolerance. Plant Physiol. 2017, 175, 486-497. [CrossRef]

194. Hundertmark, M.; Hincha, D.K. LEA (late embryogenesis abundant) proteins and their encoding genes in Arabidopsis thaliana. BMC Genom 2008, 9, 118. [CrossRef]

195. Nouri, M.Z.; Komatsu, S. Subcellular protein overexpression to develop abiotic stress tolerant plants. Front. Plant Sci. 2013, 4, 2. [CrossRef] [PubMed]

196. Yu, J.; Cheng, Y.; Feng, K.; Ruan, M.; Ye, Q.; Wang, R.; Li, Z.; Zhou, G.; Yao, Z.; Yang, Y.; et al. Genome-wide identification and expression profiling of tomato Hsp20 gene family in response to biotic and abiotic stresses. Front. Plant Sci. 2016, 7, 1215. [CrossRef] 
197. Singh, M.; Kumar, J.; Singh, S.; Singh, V.P.; Prasad, S.M. Roles of osmoprotectants in improving salinity and drought tolerance in plants: A review. Rev. Environ. Sci. Biotechnol. 2015, 14, 407-426. [CrossRef]

198. Rawat, N.; Singla-Pareek, S.L.; Pareek, A. Membrane dynamics during individual and combined abiotic stresses in plants and tools to study the same. Physiol. Plant. 2021, 171, 653-676. [CrossRef] [PubMed]

199. Sharma, A.D.; Kaur, P. Combined effect of drought stress and heat shock on cyclophilin protein expression in Triticum aestivum Gen. Appl. Plant Physiol. 2009, 35, 88-92.

200. Grigorova, B.; Vaseva, I.I.; Demirevska, K.; Feller, U. Expression of selected heat shock proteins after individually applied and combined drought and heat stress. Acta Physiol. Plant. 2011, 33, 2041-2049. [CrossRef]

201. Rakhra, G.; Sharma, A.D. Expression analysis of some boiling stable proteins (Hydrophilins) under combined effect of drought stress and heat shock in drought tolerant and susceptible cultivars of Triticum aestivum. Agricultura 2012, 81, 1-2.

202. Iriti, M.; Faoro, F. Chemical diversity and defence metabolism: How plants cope with pathogens and ozone pollution. Intern. J. Mol. Sci. 2009, 10, 3371-3399. [CrossRef]

203. Bharti, N.; Yadav, D.; Barnawal, D.; Maji, D.; Kalra, A. Exiguobacteriumoxidotolerans, a halotolerant plant growth promoting rhizobacteria, improves yield and content of secondary metabolites in Bacopa monnieri (L.) Pennell under primary and secondary salt stress. World J. Microbiol. Biotech. 2013, 29, 379-387. [CrossRef] [PubMed]

204. Krasensky, J.; Jonak, C. Drought, salt, and temperature stress-induced metabolic rearrangements and regulatory networks. J. Exp. Bot. 2012, 63, 1593-1608. [CrossRef]

205. Miller, M.A.; O'Cualain, R.; Selley, J.; Knight, D.; Karim, M.F.; Hubbard, S.J.; Johnson, G.N. Dynamic acclimation to high light in Arabidopsis thaliana involves widespread reengineering of the leaf proteome. Front. Plant Sci. 2017, 8, 239. [CrossRef]

206. Chojak-Koźniewska, J.; Kuźniak, E.; Linkiewicz, A.; Sowa, S. Primary carbon metabolism-related changes in cucumber exposed to single and sequential treatments with salt stress and bacterial infection. Plant Physiol. Biochem. 2018, 123, 160-169. [CrossRef]

207. Seki, M.; Kamei, A.; Yamaguchi-Shinozaki, K.; Shinozaki, K. Molecular responses to drought, salinity and frost: Common and different paths for plant protection. Curr. Opin. Biotechnol. 2003, 14, 194-199. [CrossRef]

208. Khan, T.A.; Yusuf, M.; Fariduddin, Q. Hydrogen peroxide in regulation of plant metabolism: Signalling and its effect under abiotic stress. Photosynthetica 2018, 56, 1237-1248. [CrossRef]

209. Chen, D.; Shao, Q.; Yin, L.; Younis, A.; Zheng, B. Polyamine function in plants: Metabolism, regulation on development, and roles in abiotic stress responses. Front. Plant Sci. 2019, 9, 1945. [CrossRef] [PubMed]

210. Singha, D.L.; Baldodiya, G.M.; Chikkaputtaiah, C. Targeting metabolic pathways for abiotic stress tolerance through genetic engineering in rice. In Rice Research for Quality Improvement: Genomics and Genetic Engineering; Roychoudhury, A., Ed.; Springer: Singapore, 2020; pp. 617-648.

211. Panda, A.; Rangani, J.; Parida, A.K. Unraveling salt responsive metabolites and metabolic pathways using non-targeted metabolomics approach and elucidation of salt tolerance mechanisms in the xero-halophyte Haloxylonsalicornicum. Plant Physiol. Biochem. 2020, 158, 284-296. [CrossRef] [PubMed] 